\title{
The Best Interests Of Incompetent Patients: The Capacity For Interpersonal Relationships as a Standard for Decisionmaking
}

\author{
Kevin P. Quinn, S.J.†
}

This Comment proposes a standard for determining when life-sustaining medical treatment may be withdrawn from incompetent patients whose wishes cannot be known. It argues that the current standards used to guide surrogate decisionmaking are unsatisfactory because they fail to address the "quality of life" considerations that necessarily underlie any determination of whether it is "worth" keeping a patient alive. Making quality of life decisions requires defining the essential characteristic of being human, which the Author proposes is the capacity for interpersonal relationships. Absent this capacity, life offers a patient no personal benefit. The "capacity for interpersonal relationships" standard not only focuses the inquiry of whether to forego an incompetent patient's life-sustaining medical treatment on the relevant factor of what it means to be alive, but also provides a socially acceptable standard that does not make relative distinctions about the value of life in a utilitarian sense. The Comment concludes by articulating guidelines by which this standard could be implemented.

\section{INTRODUCTION}

Mr. Q, fifty-five years old, is bedridden due to serious physical and mental impairments resulting from injuries sustained in an automobile accident. ${ }^{1}$ He suffered massive and irreversible damage to the parts of his brain that control thought and movement. Medical experts have asserted that, while $\mathrm{Mr}$. $\mathrm{Q}$ is not brain dead, comatose, or in a persistent vegetative state, ${ }^{2}$ his intellectual capacity is limited, and will probably

$\dagger$ A.B. 1979, Fordham University; M.Div. 1985, Jesuit School of Theology at Berkeley; third-year student, Boalt Hall School of Law; Ph.D. student, Jurisprudence and Social Pohicy Program, University of California, Berkeley.

1. This hypothetical case is a composite of several real cases. See, e.g., In re Jobes, 108 N.J. 394, 529 A.2d 434 (1987); In re Conroy, 98 N.J. 321, 486 A.2d 1209 (1985); In re Guardianship of Hamlin, 102 Wash. 2d 810, 689 P.2d 1372 (1984).

2. Each of these neurologic syndromes is medically distinct. See Cranford, The Persistent Vegetative State: The Medical Reality (Getting the Facts Straight), 18 HASTINGS CENTER ReP., February-March 1988, at 27, 27-28. Whole bram death is the cessation of both higher cerebral functions (consciousness and the control of movement) and all brain stem functions (vegetative 
never improve. Mr. $Q$ is mcontinent, requiring a catheter to empty his bladder contmuously. He cannot speak, he routinely receives enemas for bowel evacuation, his ability to swallow has deteriorated dramatically, and he is fed through a gastrostomy tube. ${ }^{3}$

On the other hand, Mr. $\mathrm{Q}$ does imteract with his environment in some limited ways: he moans occasionally when moved or when his bandages are changed; at tinnes he pulls at his bandages, feeding tube, and catheter; his eyes sometimes follow individuals in the room; and his facial expressions change on occasion.

Complications witl the gastrostomy tube have forced the attending physicians to consider other surgical procedures to provide Mr. $Q$ with adequate nutrition, ${ }^{4}$ without which he will die from starvation. Despite this dire prognosis, the attending physicians have concluded that surgical intervention is inappropriate in this case because the patient will gam no medical benefit from this intrusive surgery and has no reasonable hope of recovery or of returning to cognitive life.

A court has declared $\mathrm{Mr}$. $\mathrm{Q}$ incompetent to make decisions about his medical treatment. Mr. $Q$ has no family, relatives, or close friends whom the medical staff, a gnardian ad litem, or the court could consult concerning his treatment. He is an incompetent patient whose wishes concerning the continuance or discontinuance of life-sustaining medical treatment are unknown. ${ }^{5}$ How is any surrogate decisionmaker to evaluate Mr. Q's best interests? What standards should a physician, guardian, or court use to decide whether the proposed surgery for this particular incompetent $t^{6}$ patient is ethically or legally mandated?

functions such as eye movements, spontaneous respiration, coughing, and swallowing). By contrast, a patient in a persistent vegetative state (PVS) has a relatively intact brain stem and manifests a variety of normal brain stem functions. A PVS patient is unconscious, but not comatose. "A coma is a state of sleeplike (eyes-closed) unarousability due to extensive damage to the reticular activating system of the brain stem." Id. at 28. Unlike PVS patients, comatose patients often have impaired cough and swallowing refiexes, and therefore "typically do not experience the long-term survival period associated with the vegetative state." Id.

3. A gastrostomy is the surgical implantation of a feeding tube directly through the abdominal wall into the stomach.

4. Mr. Q could be fed through a jejunostomy tube-a tube inserted through a hole in the abdominal cavity into the jejunum of the small intestine.

5. The classic case of an incompetent patient whose wishes are unknown is the person who has no one who can relate articulated wishes concerning life-sustaining medical treatment. See, e.g., Superintendent of Belchertown State School v. Saikewicz, 373 Mass. 728, 370 N.E.2d 417 (1977). However, the existence of family or friends does not necessarily preclude the possibility that an incompetent patient's wishes might still remain totally unknown.

6. By incompetence, I mean "decisionmaking incapacity." This is "not a medical or psychiatric diagnostic category; it rests on a judgment of the type that an informed layperson might make- that a patient lacks sufficient ability to understand a situation and to make a choice in light of that understanding." President's Comm'N for the STUdY OF ETHICAL Problems iN Medicine and Blomedical and Behavioral Research, Deciding to Forego lifeSustaining Treatment: A Report on the Ethical, Medical and Legal issues in 
The tragic case of Mr. Q is not unique. With the explosive growth of technology, an increasingly aged population and an ever stronger insistence on the rights of patients to refuse treatment, the decision to forego administering life-sustaining medical treatınent to an incompetent patient whose wishes cannot be known is now commonplace. Although advances in medical science and technology are forcing us to redefine what it means to be alive in some hunianly meaningful way, public discussion of the novel questions raised by these advances has seldoin candidly raised fundamental questions about hunian values and dignity underlying that redefinition. Likewise, courts have been reluctant to articulate fundamental moral values as guideposts for surrogate decisionmaking concerning life-sustaining medical treatment. ${ }^{7}$ Surrogate decisionmaking for an incoinpetent patient whose wishes cannot be known requires clarification of societal values. Absent guidance from state legislatures and faced continually with such cases, courts can no longer abdicate their responsibility to identify socially acceptable moral guideposts.

Traditional jurisprudence in this area has tended to focus on the patient's personal autonomy. The competent patient's right to refuse medical treatinent has been gradually extended through judicial adoption of surrogate decisionmaking to include those who are not competent. By applying the "substituted judgnient" standard, ${ }^{8}$ courts intend to ensure that the surrogate decisionmaker effectuates, to the extent possible, the decision the patient would make if he or she were competent.

Treatment Decisions 123 (1983) [hereinafter President's Comm'N]; cf. Perl \& Shelp, Psychiatric Consultation Making Moral Dilemmas in Medicine, 307 NEw ENG. J. MED. 618, 620 (1982) ("[i]t appears to serve no legitimate purpose for inedicine to mask moral choices as psychiatric problems"). Compare Hastings' CenTER, gUidelines on the Termination OF Life-Sustaining TREATMENT AND the CARE OF THE Dying 131 (1987) [hereinafter Hastings' GUIDELINES] ("These Guidelines define decisionmaking capacity as: (a) the ability to comprehend information relevant to the decision; (b) the ability to deliberate about the choices in accordance with personal values and goals; and (c) the ability to communicate (verbally or nonverbally) with caregivers.").

Among incapacitated patients, several clinically distinct categories exist: patients who are brain dead; patients in a persisfent vegetative state; severely and irreversibly deniented patients; and elderly patients with permanent mild impairment of competence. See Wanzer, Adelstein, Cranford, Federman, Hook, Moertel, Safar, Stone, Taussig, \& van Eys, The Physician's Responsibility Toward Hopelessly Ill Patients, 320 N. ENG. J. MED. 955, 958-59 (1984) [hereinafter Wanzer \& Adelstein]; see also Johnson, Withholding Fluids and Nutrition: Identifying the Populations at Risk, 2 IssUES L. \& MED. 189 (1980).

7. But see In re Conroy, 98 N.J. 321, 399, 486 A.2d 1209, 1250 (1985)(Handler, J., concurring in part and dissenting in part)

("[O]ur understanding as to how life should end must be infused with the fundamental human moral values that serve us while we live. As we lave faced life, so should we be able to face death .... [A] decision informed by these considerations would be conducive to the humane, dignified, and decent ending of life.").

8. For discussion of the "substituted judgment" test, see In re Conroy, 98 N.J. 321, 360, 486 A.2d 1209, 1229 (1985); In re Quinlan, 70 N.J. 10, 41, 355 A.2d 647, 664, cert. denied, 429 U.S. 922 (1976); infra notes 69-93 and accompanying text. 
However, what if the wishes of the incompetent patient cannot be known? Absent clear and convincing proof of the patient's subjective desires, courts have applied more "objective" standards. ${ }^{9}$ Under these objective tests, the surrogate decisionmaker inust prove that the burdens of continued life to the patient clearly and markedly outweigh the benefits before life-sustaining treatinent inay be withheld. ${ }^{10}$ The courts applying this objective balancing test have focused solely on physical pain as experienced by the incompetent patient. ${ }^{11}$ Courts have uniformly failed to discuss adequately how to evaluate the benefits of a particular patient's life to that patient, thereby avoiding problematic quality of life considerations.

However, because a decision to forego life-sustaining treatment necessarily involves comparing the kind of life this patient is capable of living with and without treatment, courts inust inevitably make some "quahty of life" determination. ${ }^{12}$ The question therefore becomes how the surrogate decisionmaker is to determine the best interests of an incompetent patient whose wishes cainıot be known ${ }^{13}$ without imposing his or her own values on the decisionmaking process.

A surrogate decisionmaker needs a demonstrably objective standard which embodies socially acceptable values to evaluate the kind of life possible to an incompetent patient with and without treatment. A carefully defined standard would prevent the inpermissible imposition of purely subjective values or notions of social utility ${ }^{14}$ on the decisionmaking process. This Comment therefore proposes a "quahity of life" standard for surrogate decisionmaking grounded in a philosophical notion of "person" which is accessible to all.

Based largely on Kant's deontological ethics as interpreted by cer-

9. See, e.g., Conroy, 98 N.J. at 365, 486 A.2d at 1232.

10. Id. For further discussion of the two objective tests, the "limited-objective" and "pureobjective," see infra notes 111-18 and accompanying text.

11. See, e.g., Conroy, 98 N.J. at 366, 486 A.2d at 1232. For criticism of this exclusive focus on pain, see infra notes 121-33 and accompanying text.

12. See infra notes $166-73$ and accompanying text.

13. Concern over this class of incompetent patient was poignantly expressed in Justice Handler's concurring opinion in the recent Jobes decision. In re Jobes, 108 N.J. 394, 529 A.2d 434 (1987). In that case, the New Jersey Supreme Court held that family members could make a substituted judgment for an irreversibly vegetative patient who had not clearly expressed her medical preferences while she was competent, id. at 420,529 A.2d at 447 , because there was some "trustworthy" evidence that the patient, if competent, would have wanted a feeding tube removed. Id. at 419-20, 529 A.2d at 447. Justice Handler's concern was with the extreme case not presented in Jobes: "We should grapple with the question of what we are to do if Nancy Ellen Jobes had had no one to inform us as to her feelings or wishes in the matter." Id. at 441,529 A.2d at 458 (Handler, J., concurring). This Comment is similarly concerned with this extreme casc.

14. To consider a person's continued usefulness and value to society as a measure of whether a person should be kept alive treats that person's life as a means to an end and not an end to be valued in itself. This Comment rejects this approach as unethical. 
tain contemporary authors, ${ }^{15}$ this Comment draws a distinction between human personal life and human biological life, with the latter viewed as the condition for the possibility of the former. Under this philosophical construct, contmued life does not constitute a good unless it offers the necessary conditions of meaningful personal existence. ${ }^{16}$ This approach requires defining explicitly the values whicli society should recognize as giving meaning to the human life.

The meaning and substance of life, this Comment argues, is found in personal relationships. As ethicists have contended, this emphasis on the capacity to relate to otlier human beings is deinonstrably objective, adequately captures the dignity of personhood, and avoids a subjective evaluation of a person's self-worth by another. ${ }^{17}$ In any decision to withhold life-sustaining treatinent, a surrogate decisionmaker should judge the prospective quality of life for an individual patient by evaluating that patient's capacity for interpersonal relationships. If the surrogate decisionmaker is assured by medical staff that an individual's capacity for interpersonal relationships is irretrievably lost, lie may permissibly decide that it is in the best interests of the patient to withhold life-sustaining treatment. ${ }^{18}$

This Comment argues that the capacity for interpersonal relationships is an objectively defensible "quality of life" standard whicli provides surrogate decisionmakers witlı a legitiniate means for determining the best interests of an incoinpetent patient whose wishes cannot be known. Part I of this Comment charts the flurry of legal activity in this area since 1976. After reviewing the einergence of the right to refuse medical treatinent in coinpetent patients, this Coinment next highliglits the developinent of legal principles extending this right to incompetent patients. Part II addresses tlie unsettled legal question of how to identify the "best interests" of an incoinpetent patient whose wishes cannot be known. After reviewing tlie judicial standards articulated by various courts to guide surrogate decisionmaking, this Comment analyzes wliy the courts have failed to identify the "best interests" for this class of mcompetent patients. Part III suggests a solution by proposing a "quality of life" standard. After outliming the basic concept of personhood, this Cominent presents operational criteria for applying the "quality of life" standard. Finally, the proposed standard is applied to the liypotlietical case of Mr. Q.

15. See, e.g., H. T. ENGELhaRdT, JंR., The Foundations of Bloethics (1986), discussed infra note 175.

16. See infra notes $174-80$ and accompanying text.

17. See infra notes $181-96$ and accompanying text.

18. See infra notes 203-05 and accompanying text. 


\section{I}

The Evolution Of The Legal Right To Forego LifeSUSTAINING MEDical TREATMENT

\section{A. The Right of Competent Patients to Refuse Medical Treatment}

A patient's right to refuse medical treatment, even lifesaving medical care, is secured by both the common law right to freedom from nonconsensual invasions of bodily integrity and the federal constitutional right to privacy in making individual inedical treatinent decisions. In addition, a number of states have adopted statutes codifying these principles. The right to refuse life-sustaining medical treatment is not absolute, however, whether premised on common law doctrine, on constitutional theory or on statutory law.

\section{The Common Law Right to Bodily Integrity}

The common law has long recognized an individual's right to freedom froin nonconsensual imvasions of bodily integrity. ${ }^{19}$ Similarly, American courts and legal commentators ${ }^{20}$ have einphasized the importance of personal decisionmaking autonoiny, particularly in the sphere of medical care.

Since its enunciation over three decades ago, ${ }^{21}$ the doctrine of inforined consent has become the primary legal means of protecting the common law right to bodily integrity in the medical context. "Under this doctrine, no medical procedure may be perforned without a

19. See, e.g., Union Pac. Ry. v. Botsford, 141 U.S. 250, 251 (1891) (refusing to compel personal injury plaintiff to undergo pretrial medical examination) ("No right is held nore sacred, or is more carefully guarded, by the common law, than the right of every individual to the possession and control of his own person, free froin all restraint or interference of others, unless by clear and unquestionable authority of law."); see also Schloendorff v. Soe'y of New York Hosp., 211 N.Y. 125, 129-30, 105 N.E. 92, 93 (1914) ("Every human being of adult years and sound nind has a right to determine what shall be done with his own body ....").

This right "can be interpreted as protecting two interests: the interest in being free from nonconsensual bodily invasion and the interest in decisionmaking autonomy." Comment, Suicidal Competence and the Patient's Right to Refuse Lifesaving Treatment, 75 CALIF. L. Rev. 707, 721 (1987) (authored by Martha Matthews).

20. See, e.g., HASTINGs' Guidelines, supra note 6, at 7:

[O]ur ethical framework draws on the value of patient autonony or self-determination, which establishes the right of the patient to determine the nature of his or her own inedical care. This valne reflects our society's long standing tradition of recognizing the unique worth of the individual. We respect human dignity by granting individuals the freedom to make choices in accordance with their own values. The principle of autonoiny is the moral basis for the legal doctrine of informed consent, which includes the right of informed refusal.

See also N. Cantor, Legal Frontiers of Death and Dying 8-9 (1987); President's Comm'N, supra note 6, at 26.

21. See Salgo v. Leland Stanford Jr. Univ. Bd. of Trustees, 154 Cal. App. 2d 560, 578, 317 P.2d 170, 181 (1957); see generally Meisel, The Expansion of Liability For Medical Accidents: From Negligence to Strict Liability By Way of Informed Consent, 56 Neb. L. REv. 51, 77-86 (1977) (discussing the origins of the informed consent doetrine). 
patient's consent, obtained after explanation of the nature of the treatment, substantial risks, and alternative therapies."22 Substantially expanding upon these central legal traditions of bodily integrity and personal autonoiny, numerous courts have recognized the refusal of life-sustaining medical treatment by coinpetent individuals as a common law right. $^{23}$

\section{The Federal Constitutional Right to Privacy}

Bodily integrity is also protected by the federal constitutional right to privacy. Although the United States Constitution does not provide exphcitly for a right to privacy, the United States Supreme Court has recognized that a right to privacy exists and is protected by the Constitution. ${ }^{24}$

The Court first articulated this federal constitutional right in Griswold v. Connecticut, ${ }^{25}$ holding that married couples have a constitutional right to use contraceptives. ${ }^{26}$ The unwritten fundamental right of privacy was found to exist in the "penumbra" of specific guarantees of particular amendments to the Constitution "formed by emanations from

22. Cantor, A Patient's Decision to Decline Life-Saving Medical Treatment: Bodily Integrity Versus the Preservation of Life, 26 RuTGERS L. REV. 228, 237 (1973) (footnotes omitted); see also Wanzer \& Adelstein, supra note 6, at 957:

There are three basic prerequisites for informed consent: the patient must have the capacity to reason and make judgments, the decision must be made voluntarily and without coercion, and the patient must have a clear understanding of the risks and benefits of the proposed treatment alternatives or nontreatment, along with a full understanding of the nature of the disease and the prognosis.

23. See, e.g., Natanson v. Kline, 186 Kan. 393, 405-07, 350 P.2d 1093, 1104, clarified 187 Kan. 186, 354 P.2d 670 (1960) (one of the first of the modern line of cases to acknowledge expressly the competent adult patient's right to refuse lifesaving medical treatment); In re Gardner, 534 A.2d 947, 952 (Me. 1987); In re Eicliner, 73 A.D.2d 431, 454, 426 N.Y.S.2d 517, 536 (1980), modified, 52 N.Y.2d 363, 420 N.E.2d 64, 438 N.Y.S.2d 266 (1981); accord Bartling v. Superior Court, 163 Cal. App. 3d 186, 209 Cal. Rptr. 220 (1984) (extending right to withdraw life-support treatment to incurably, though not terminally, ill competent adult patients). See, eg., Rasmussen v. Fleming, 154 Ariz. 207, 214-16, 741 P.2d 674, 683 (1987); Foody v. Manchester Memorial Hosp., 40 Conn. Supp. 127, 130-34, 482 A.2d 713, 717-18 (1984); Brophy v. New England Sinai Hosp., 398 Mass. 417, 430, 497 N.E.2d 626, 633 (1986); In re Farrell, 108 N.J. 335, 348, 529 A.2d 404, 411; In re Guardianship of Grant, 109 Wash. 2d 545, 553, 747 P.2d 445, 449 (1987) cf. In re Conservatorship of Torres, 357 N.W.2d 332, 339-40 (Minn. 1984) (recognizing constitutional and common law right but premising its holding on constitutional and statutory right); Conroy, 98 N.J. at 348, 486 A.2d at 1209 (recognizing constitutional right but limiting its holding to apphication of common law right); In re Storar, 52 N.Y.2d 363, 376, 420 N.E.2d 64, 70, 438 N.Y.S.2d 266, 272-73, cert. denied, 454 U.S. 858 (1981) (premising its holding on "common law principles," noting that whether right to refuse medical treatment is guaranteed by the Constitution is a "disputed question").

24. See, e.g., Roe v. Wade, 410 U.S. 113 (1973) (abortion); Griswold v. Connecticut, 381 U.S. 479 (1965) (contraception for married couples). But see Bowers v. Hardwick, 478 U.S. 186 (1986) (right to privacy does not encompass right to engage in homosexual sodomy).

25. 381 U.S. 479 (1965).

26. Cf. Carey v. Population Services Int', 431 U.S. 678 (1977) (right to privacy prohibits burdensoine regulation of the sale and distribution of contraceptives); Eisenstadt v. Baird, 405 U.S. 438 (1972) (extending the right to use contraceptives to non-married couples). 
those guarantees that help give them life and substance."27 The Court's recognition of a privacy right was later dramatically extended to the abortion context, in the landmark case of Roe v. Wade. ${ }^{28}$ The Court found this privacy right to be part of the "liberty" guaranteed by the fourteenth amendinent and "broad enough to encompass a woman's decision whether or not to terminate her preguancy."29 Therefore, in terms of due.process and equal protection, the right to privacy has come to mean a right to engage in certam highly personal activities. ${ }^{30}$ This right embraces both an "individual interest in avoiding disclosure of personal matters" and an "mterest in independence in making certain kinds of important decisions." 11

The Supreme Court has not explicitly established the right to refuse medical treatment as a separate fundamental protected interest. ${ }^{32}$ Nonetheless, the New Jersey Supreme Court, in its landmark decision In re Quinlan, ${ }^{33}$ became the first state supreme court to hold that the federal constitutional right to privacy encompasses the right to forego life-sustaining medical treatment. The Quinlan court found the right to privacy "broad enough to encompass a patient's decision to decline medical treatment under certain circumstances ...."34 A number of other state courts have followed the Quinlan court's lead. ${ }^{35}$

27. Griswold, 381 U.S. at 484. The majority opinion, authored by Justice Douglas, claimed that "emanations" from the first, third, fourth, fifth, and ninth amendnients collectively establish a "penumbra" in which "privacy is protected froin government nitrusion." See also Roe, 410 U.S. at 152.

28. 410 U.S. 113 (1973).

29. Id. at 153 .

30. In addition to contraception and abortion, these activities include family matters, reproduction, and nuarriage. The Supreme Court, in pre-Griswold decisions, had implicitly recognized the right of private decisionnaking regarding family matters and reproduction as inherent in the concept of liberty. See Skinner v. Oklahoma, 316 U.S. 535 (1942) (invalidating a state statute that authorized the sterilization of persons previously convicted and sentenced to imprisonment two or inore times for crimes of "nioral turpitude"); Pierce v. Soc'y of Sistcrs, 268 U.S. 510 (1925) (nivalidating statute that required students to attend public rather than private schools); Meyer v. Nebraska, 262 U.S. 390 (1923) (invalidating a statute that prohibited all grade schools froin teaching subjects in any language other than English). The right to freedom of choice in marriage was first described as a privacy right in Justice Harlan's dissenting opinion in Poe v. Ullman, 367 U.S. 497, 522 (1961) (Harlan, J., dissenting), and was embraced by the Court on equal protection grounds in Loving v. Virginia, 388 U.S. 1 (1967).

31. Whalen v. Roe, 429 U.S. 589, 599-600 (1977).

32. But see Doe v. Bolton, 410 U.S. 179, 213 (Douglas, J., concurring) ("the freedom to care for one's health and person" is a fundamental right).

33. 70 N.J. 10, 355 A.2d 647, cert. denied, 429 U.S. 922 (1976).

34. Id. at $40,355 \mathrm{~A} .2 \mathrm{~d}$ at 663 .

35. See, e.g., Superintendent of Belchertown State School v. Saikewicz, 373 Mass. 728, 742, 370 N.E.2d 417, 426 (1977):

The Constitutional right to privacy, as we conceive it, is an expression of the sanctity of individual free choice and self-deternimation as fnndamental constituents of life. The value of life as so perceived is lessened not by a decision to refuse treatnient, but by the failure to allow a competent human being the right of choice. 
The preceding constitutional analysis involves a weighing of the patient's right to privacy against the countervailing state interests. Most state courts considering this issue have identified four such interests: (1) preserving life; (2) preventing suicide; (3) safeguarding the integrity of the medical profession; and (4) protecting innocent third parties. ${ }^{36}$

These courts have generally considered the preservation of life the most significant state interest. ${ }^{37}$ Nonetheless, absent special circumstances, ${ }^{38}$ this abstract interest usually yields to the patient's much stronger constitutional right to privacy. ${ }^{39}$ Courts have circumvented the state's interest in preventing suicide by designating the underlying disease rather than the removal of life-sustaining medical treatment as the cause of death. ${ }^{40}$ Under this approach, most courts have reasoned that

See also Rasmussen v. Fleming, 154 Ariz. 207, 215, 741 P.2d 674, 682 (1987) (en banc) ("The right to refuse medical treatment is a personal right sufficiently 'fundamental' or 'implicit in the concept of ordered liberty' to fall within the constitutionally protected zone of privacy contemplated by the Supreme Court."); Bouvia v. Superior Court, 179 Cal. App. 3d 1127, 1141, 225 Cal. Rptr. 297, 304 (1986); Foody v. Mancliester Memorial Hosp., 40 Conn. Supp. 127, 131, 482 A.2d 713, 717 (1984); In re Severns, 425 A.2d 156, 158 (Del. Cl. 1980), enforcing 421 A.2d 1334 (Del. 1980); John F. Kennedy Memorial Hosp. v. Bludworth, 452 So. 2d 921, 924 (Fla. 1984); Brophy v. New England Sinai Hosp., 398 Mass. 417, 430, 497 N.E.2d 626, 633 (1986); In re Farrell, 108 N.J. 335, 348, 529 A.2d 404, 410 (1987); Leach v. Akron General Medical Center, 68 Ohio Misc. 1, 8-9 (1980); In re Guardianship of Grant, 747 P.2d 445, 449 (1987). Many states have recognized that the right to refuse life-sustaining medical treatment is both a common law and constitutional right. See, e.g., Rasmussen v. Fleming, 154 Ariz. 207, 214-16, 741 P.2d 674, 683 (1987); Foody v. Mancliester Memorial Hosp., 40 Conn. Supp. 127, 130-34, 482 A.2d 713, 717-18 (1984); In re Conservatorship of Torres, 357 N.W.2d 332, 339.40 (Minn. 1984) (recognizing constitutional and common law riglit but premising its loolding on constitutional and statutory right).

36. See, e.g., Fleming, 154 Ariz. at 216-17, 741 P.2d at 683-85; Brophy, 398 Mass. at 431, 497 N.E.2d at 634; In re Conservatorship of Torres, 357 N.W.2d 332, 339 (Minn. 1984); In re Conroy, 98 N.J. 321, 348, 486 A.2d 1209, 1223 (1985); Grant, 109 Wash. 2d at 556-57, 747 P.2d at 451; see also President's CoMm'N, supra note 6, at 31-32.

37. This state interest embraces two separate but related concerns: "an interest in preserving the life of the particular patient, and an interest in preserving the sanctity of all life." Conroy, 98 N.J. at 348, 486 A.2d at 1223; see also cases cited supra note 36.

38. See, e.g., Roe v. Wade, 410 U.S. 113, $164-65$ (1973) (authorizing state regnlation or proscription of woman's right to abortion in the stage of pregnancy subsequent to viability in order to protect the state's interest in potential human life).

39. See, e.g., In re Quinlan, 70 N.J. 10, 40-41, 355 A.2d 647, 664, cert. denied, 429 U.S. 922 (1976) (individual's right to privacy overcoines state interest "as the degree of bodily invasion increases and the prognosis dims"); see also Fleming, 154 Ariz. at 217, 741 P.2d at 683; Conroy, 98 N.J. at 353, 486 A.2d at 1223-24. C

40. See Satz v. Perlmutter, 362 So. 2d 160, 162 (Fla. Dist. Ct. App. 1978), approved, 379 So. 2d 359 (Fla. 1980); Superintendent of Belchertown State School v. Saikewicz, 373 Mass. 728, 743 n.11, 370 N.E.2d 417, 426 n.11 (1977); Conroy, 98 N.J at 355, 486 A.2d at 1224; see also PRESIDENT's CoMm'N, supra note 6, at 38 (summarizing case law on the subject). But see In re Conroy, 190 N.J. Super. 453, 475, 464 A.2d 303, 315 (1983), rev'd, 98 N.J. 321, 486 A.2d 1209 (1985) (elnpliasis added):

If the trial judge's order had been enforced, Conroy would not liave died as the result of an existing inedical condition, but rather she would have died, and painfully so, as the result of a new and independent condition: delydration and starvation. Thus, she would have been actively killed by independent means rather than allowed to die of existing illness or injury. 
asserting the right to decline life-sustaining medical treatment is not equivalent to committing suicide. ${ }^{41}$

Similarly, permitting competent patients to forego life-sustaining medical treatment does not threaten the state's interest in safeguarding the integrity of the medical profession. Just as the inedical profession itself now recognizes that it is no longer obligated to provide inedical treatinent in all circumstances, ${ }^{42}$ most courts have recognized that health care standards are not undermined by a competent and informed patient's refusal of life-sustaining medical treatment. ${ }^{43}$

When refusing to allow a competent patient to forego life-sustaining treatment, courts almost always invoke the state's interest in protecting third parties. In these relatively rare decisions, either the patient has minor children, ${ }^{44}$ the medical procedures are necessary to protect the

41. See, e.g., Rasmussen v. Fleming, 154 Ariz. 207, 218, 741 P.2d 674, 685 (1987) (en banc); Bouvia v. Superior Court, 179 Cal. App. 3d 1127, 1144-45, 225 Cal. Rptr. 297, 306 (1986) ("Her decision to allow nature to take its course is not equivalent to an election to commit suicide with real parties aiding and abetting therein."); Brophy v. New England Sinai Hosp., 398 Mass. 417, 438, 497 N.E.2d 626, 638 (1986); In re Guardianship of Grant, 109 Wash. 2d 545, 556, 747 P.2d 445, 451 (1987). But cf. In re Caulk, 125 N.H. 226, 232, 480 A.2d 93, 97 (1984) (an otherwise healthy prison inmate's intentional attempt to starve himself to death is equivalent to an attempted suicide which the state can legitimately prevent).

42. Significant is the statement of the Council on Ethical and Judicial Affairs of the American Medical Association entitled Withholding or Withdrawing Life Prolonging Medical Treatment: "The social commitunent of the physician is to sustain life and reheve suffering. Where performance of one duty conflicts with the other, the choice of the patient, or his family or legal representative if the patient is incompetent to act in his own behalf, should prevail." AMERICAN MEDICAL ASSOCIATION, CURRENT OPINIONS OF THE COUNCII ON ETHICAL AND JUDICIAL AfFaIRs (Mar. 15, 1986) [hereinafter A.M.A. STATEMENT]; accord In re Storar, 52 N.Y.2d 363, 385-86 n.3, 420 N.E.2d 64, $75-76$ n.3, 438 N.Y.S.2d 266, $277-78$ n.3, cert. denied, 454 U.S. 858 (1981) (Jones, J., dissenting in part) (citing recent surveys suggesting that the majority of practicing physicians now approve of "passive euthanasia" and believe it is being practiced by meinbers of the profession); New Jersey State Board of Medical Examiners, Policy Statement of THE New Jersey STATE Board of Medical Examiners ON Decision to WITHHOld OR WITHDRAW Medical TREATMENT 1-2 (July 1986) ("coinpetent adult has the right to accept or refuse medical treatment [even when the refusal is] likely to result in death"). But cf. Micetich, Steinecker \& Thomasma, Are Intravenous Fluids Morally Required for a Dying Patient?, 143 ARCH. INTERNAL MED. 975, 976 (1983) (proposing that under specific circumstances certain fluids are not morally required for dying patients. Seventy-three percent of physicians responding to a survey soliciting opinions on this viewpoint disagreed with the authors. The authors concluded that providing these fluids as standard therapy "remains firmly entrenched in medical practice.").

43. See, e.g., Fleming, 154 Ariz. at 217, 741 P.2d at 684-85; In re Farrell, 108 N.J. 335, 351-52, 529 A.2d 404, 411-12 (1987); In re Conroy, 98 N.J. 321, 351-52, 486 A.2d 1209, 1224-25 (1985); Quinlan, 70 N.J. at 46,355 A.2d at 667.

44. E.g., In re President \& Directors of Georgetown College, 331 F.2d 1000, 1008 (D.C. Cir.), cert. denied, 377 U.S. 978 (1964) (inother of seven-month-old infant compelled to submit to blood transfusion over her rehigious objections because of her "responsibility to the community to care for her infant"); see also In re Osborne, 294 A.2d 372, 374 (D.C. 1972) (court refused to order transfusion for father, a Jehovah's Witness, in part because patient had already provided for his two children); In re Estate of Brooks, 32 Ill. 2d 361, 205 N.E.2d 435 (1965) (upholding right of inother, a Jehovah's Wituess with adult children, to forego a life-saving transfusion, noting that a different result might have obtained if minor children were imvolved); John F. Kennedy Memorial Hosp. v. 
pubhic health and well-being, ${ }^{45}$ or other significant state interests are present. ${ }^{46}$ The majority of state courts to face the issue, however, have recognized that "the right to self-determmation ordinarily outweighs any countervailing imterests, and competent patients generally are permitted to refuse medical treatment, even at the risk of death." 47

\section{The Statutory Right to Refuse Medical Treatment}

Many states have adopted statutes exphicitly codifying the common law doctrine and constitutional theory concerning the right to refuse lifesustaining medical treatment. For example, thirty-eiglit states and the District of Columbia have enacted "living will" legislation, which allows an individual anticipating possible incompetence to state that he or slie wishes to forego life-sustaining treatment should he or she become terminally ill and no longer able to make medical decisions. ${ }^{48}$ In addition,

Heston, 58 N.J. 576, 279 A.2d 670 (1971) (contrary to a tenet of her faith as a Jehovah's Witness, 22 year-old pregnant woman compelled to submit to life-saving blood transfusion).

45. E.g., Jacobson v. Massachusetts, 197 U.S 11 (1905) (enforcing compulsory smallpox vaccination law as a significant public health matter).

46. E.g., Commissioner of Corrections v. Myers, 379 Mass. 255, 399 N.E.2d 452 (1979) (young and otherwise healthy state prison inmate refused permission to forego essential hemodialysis in order to prevent serious risk to prison security).

47. In re Conroy, 98 N.J. 321, 353, 486 A.2d 1209, 1225 (1985); see, eg., Bouvia v. Superior Court, 179 Cal. App. 3d 1127, 225 Cal. Rptr. 297 (1980); In re Osborne, 294 A.2d 372 (D.C. 1972); Satz v. Perlmutter, 362 So. 2d 160 (Fla. Dist. Ct. App. 1978), approved, 379 So. $2 \mathrm{~d} 359$ (Fla. 1980); In re Estate of Brooks, 32 Ill. 2d 361, 205 N.E.2d 435 (1965); Lane v. Candura, 6 Mass. App. Ct. 377, 376 N.E.2d 1232 (1978), cited with approval in Brophy v. New England Sinai Hosp., 398 Mass. 417,497 N.E.2d 626 (1986).

48. ALA. CODE $\S \S 22-8 \mathrm{~A}-1$ to 22-8A-10 (1984); ALASKA STAT. $\$ \$ 18.12 .010-18.12 .100$ (1986); ARIZ. REv. STAT. ANN. §§ 36-3201 to 36-3210 (1986); ARK. STAT. ANN. §§ 82-3801 to 823804 (Supp. 1985); CAL. HeAlTH \& SAFETY CODE §§ 7185-7195 (West Supp. 1988); Colo. Rev. STAT. $\$ \S 15-18-101$ to $15-18-113$ (1987); CoNN. GeN. Stat. ANN. $\S \S 19 \mathrm{a}-570$ to $19 \mathrm{a}-575$ (West Supp. 1988); DEL. CODE ANN. tit. 16, $\S \S 2501-2508$ (1983); D.C. CODE ANN. $\$ \S 6-2401$ to 6-2430 (Supp. 1987); FLA. STAT. ANN. §§ 765.01-765.15 (West 1986); GA. CODE ANN. §§ 31-32-1 to 3132-12 (Supp. 1985); 1986 Haw. Sess. Laws 718; IDAHo CodE $\S \S 39-4501$ to 39-4508 (1985 \& Supp. 1987); III. ANN. STAT. ch 110 1/2, para. $701-710$ (Smith-Hurd Supp. 1987); IND. CODE ANN. $\S \S 16-8-11-1$ to 16-8-11-22 (West Supp. 1987); Iowa CODE ANN. §§ 144A.1-144A.11 (West Supp. 1988); KAN. STAT. ANN. $§ \$ 65-28,101$ to 65-28,109 (1985); LA. REv. STAT. ANN. $\S \$ 40: 1299.58 .1$ 40:1299.58.10 (West Supp. 1988); ME. Rev. StAT. ANN. tit. 22, $§ \S 2921-2931$ (Supp. 1987); MD. Health-Gen. Code ANN. $\S \S 5-601$ to 5-614 (Supp. 1987); Miss. Code ANN. $\$ \S 41-41-101$ to $41-$ 41-121 (Supp. 1987); Mo. ANN. STAT. \$\$ 459.010-459.055 (Vernon Supp. 1988); MONT. CODE ANN. §§ 50-9-101 to 50-9-111 (1987); NEv. REv. STAT. $\$ \S 449.540-449.690$ (1986 \& Supp. 1987); N.H. REv. STAT. ANN. $\S$ 137-H:1 to 137-H:16 (Supp. 1987); N.M. STAT. ANN. §§ 24-7-1 to 24-710 (1986); N.C. GEN. STAT. \$\$ 90-320 to 90-322 (1985); OKLA. STAT. ANN. tit. 63, \$§ 3101-3111 (West Supp. 1988); OR. REv. STAT. $\S \S 97.050-97.090$ (1984 \& Law Co-op. Supp. 1987); S.C. CODE ANN. $\S \S 44-77-10$ to 44-77-160 (Supp. 1987); TENN. CODE ANN. $\S \S 32-11-101$ to 32-11-110 (Supp. 1987); TeX. Rev. Crv. STAT. ANN. art. 4590h (Vernon Supp. 1988); UTAH CODE ANN. §§ 75-21101 to 75-2-1118 (Supp. 1987); VT. STAT. ANN. tit. 18, \$§ 5251-5262 (1987); VA. CoDE ANN. $\S \S 54-325.8: 1$ to 54-325.8:12 (Supp. 1987); WASH. REV. CODE ANN. $\$ \S 70.122 .010-70.122 .905$ (Supp. 1988); W. VA. CoDE $\S \S 16-30-1$ to $16-30-10$ (1985); WIS. STAT. ANN. $\$ \S 154.01-154.15$ (West Supp. 1987); WYo. STAT. §§ 35-22-101 to 35-22-109 (Supp. 1987). 
through durable powers of attorney for health care an individual can identify a person to make his or her health care decisions in the event of the patient's incompetence. ${ }^{49}$ Most states have enacted or have pending such durable power of attorney laws. ${ }^{50}$ States have also enacted various patients' rights laws further defining protections and the right to control treatment. ${ }^{51}$

\section{B. The Right of Incompetent Patients Whose Wishes Are Known to Refuse Medical Treatment}

It is axiomatic that the value of human dignity and bodily integrity extends to all human beings, whether competent or not. ${ }^{52}$ By adopting surrogate decisioninaking procedures, the courts have gradually extended the right to refuse lifesaving medical treatment to those who are not competent. ${ }^{53}$

49. A durable power of attorney is a power of attorney by which a principal designates another his attorney in fact in writing and the writing contains the words "This power of attorney shall not be affected by subsequent disability or incapacity of the principal," or "This power of attorney shall become effective upon the disability or incapacity of the principal," or similar words showing the intent of the principal that the authority conferred shall be exercisable notwithstanding the principal's subsequent disability or incapacity. UNIF. DURABLE POWER OF ATTORNEY ACT $\S 1,8$ U.L.A. 74 (1982) (reprinted in PRESIDENT's COMM'N, supra note 6 at 391).

50. Virtually all of these statutes have been inodelled on four acts: (1) VA. CODE ANN. $\$ \$ 11-$

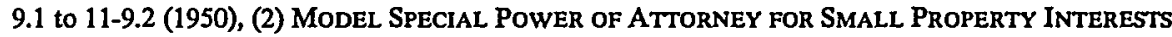
ACT (Uniform Law Commissioners 1964); (3) UN1F. Probate Code $§ \S 5-501$ to 5-502 (1969); and (4) UNIF. Durable Power of AtTorney ACT $\$ \S 1-10,8$ U.L.A. 74 (1982). President's COMM'N, supra note 6 , at 146 n.77. Only three states have durable power of attorney statutes specifically directed at health care decisions. See CAL. Civ. Code $\$ 2432$ (West Supp. 1988); Nev. REV. STAT. ANN. $\S \S 449.740-449.800$ (Michie Supp. 1987); R.I. GEN. LAws $\$ \S 23-4.10-1$ to 234.10-2 (Supp. 1987). "[H] 79,529 A.2d 419, 426 (1987)] held that the state's general durable power of attorney statute applied to health care decisions." National Legal Center Staff, Medical Treatment for Older People and People with Disabilities: 1987 Developments, 3 IssuES IN L. \& MED. 333, 358 (1988) [hereinafter National Legal Center Staff].

51. For informed consent statutes, see, e.g., FLA. StAT. ANN. $\S 768.46$ (West 1986); N.Y. MENTAL HYG. LAW $\S 2805-d .1$ (McKinney 1985 \& Supp. 1988). For statutes addressing patient access to and confidentiality of medical records, see, e.g., MASs. ANN. LAws ch. 111, $\S 70$, ch. 112, $\S 12$ G (Law. Co-op 1985 \& Supp. 1988); N.Y. MENTAL HYG. LAw $\S 33.13$ (Consol. 1979 \& Supp. 1987). For statutes governing patients' rights generally, see, e.g., MASs. ANN. LAws ch. 11, $\$ 70 \mathrm{E}$ (Law. Co-op 1985 \& Supp. 1988).

52. See, e.g., In re Eichner, 73 A.D.2d 431, 464-65, 426 N.Y.S.2d 517, 542-43 (1980), modified, 52 N.Y.2d 363, 420 N.E.2d 64, 438 N.Y.S.2d 266 (1981):

We... conclude that by standards of logic, morality and medicine the terminally ill should be trcated equally, whether competent or incompetent. Can it be doubted that the 'value of human dignity extends to both'? What possible societal policy objeetive is vindicated or furthered by treating the two groups of terminally ill differently? What is gained by granting such a fundamental right only to those who, though terminally ill, have not suffered brain damage and coma in the last stages of the dying process?

(emphasis in original; citations omitted).

53. See infra notes 69-118 and accompanying text (discussing various judicial standards to gnide surrogate decisionmaking). 
In re Quinlan, ${ }^{54}$ decided in 1976, was the first major decision establishing that life-sustaining medical interventions may, in certain circumstances, be withdrawn from an incompetent patient in a persistent vegetative state. ${ }^{55}$ Considered the leading case in this area, Quinlan established the basic principles followed by almost every court subsequently confronting this issue..$^{56}$

This highly publicized case involved Karen Ann Quinlan, a twentyone year-old who was admitted to a hospital emergency room after her breathing ceased for at least two fifteen-minute periods. ${ }^{57}$ Subsequently diagnosed as being in a "chromc persistent vegetative state" 58 with no hope of recovering cognitive or sapient life, ${ }^{59}$ inedical experts believed that Ms. Quinlan could not survive without the assistance of a respirator. ${ }^{60}$ Her father souglit to be appoimted her personal guardian and requested the express power to authorize the discontinuance of "all extraordinary inedical procedures now allegedly sustaining Karen's vital processes . ..."

In a unaninous decision, the New Jersey Supreme Court ruled that a decision to terminate life could be inade by a natural guardian (for example, the next of kin) with the concurrence of the attending plysician, the family, and the medical institution's ethics conmittee. ${ }^{62}$ The language of the court concerning the right of an incompetent to forego life-sustaining treatment is unambiguous:

If a putative decision by Karen to permit this non-cognitive, vegetative existence to terminate by natural forces is regarded as a valuable incident of her right to privacy, as we believe it to be, then it sliould not be discarded solely on the basis thiat her condition prevents her conscions

54. 70 N.J. 10, 355 A.2d 647, cert. denied, 429 U.S. 922 (1976); see N. CANTOR, supra note 20, at 59-60, for an excellent discussion of Quinlan.

55. In a persistent vegetative state, a human being loses what makes him or her a distinctive person-personality, memory, social interaction, and sentience. See supra note 2; Wanzer \& Adelstein, supra note 6, at 958. Compare PRESIDENT's COMM'N, supra note 6, at 174 n.9 (preferring use of the term "permanent loss of consciousness").

56. See, e.g., cases cited infra notes 156-62.

57. Quinlan, 70 N.J. at $22-24,355$ A.2d at $653-54$.

58. 70 N.J. at 24,355 A.2d at 654 .

59. Id. at $24,355 \mathrm{~A} .2 \mathrm{~d}$ at 655 .

60 . Id. at 25,355 A.2d at 655 .

61. Id. at $18,355 \mathrm{~A} .2 \mathrm{~d}$ at 651 .

62. Upon the concurrence of the guardian and family of Karen, should the responsible attending physicians conclude that there is no reasonable possibility of Karen's ever emerging from her present comatose condition to a cognitive, sapient state and that the life-support apparatus now being administered to Karen should be discontinued, they shall consult with the hospital 'Ethics Committee' or like body of the institution in which Karen is then hospitalized. If that consultative body agrees that there is no reasonable possibility of Karen's ever einerging from her present comatose condition to a cognitive, sapient state, the present life-support system may be with-drawn ....

Id. at $54,355 \mathrm{~A} .2 \mathrm{~d}$ at 671 . 
exercise of the choice. ${ }^{63}$

According to the court, the only practical way to protect Ms. Quinlan's right to privacy was to permit her guardian and family to decide, based on input from the attending physicians and subject to review by the hospital ethics committee, whether she would have terminated life-sustaining treatment had she been competent. ${ }^{64}$ The court therefore ordered the trial court to appoint Joseph Quinlan guardian of his incompetent daughter "with full power to make decisions with regard to the identity of her treating physicians."65 Mr. Quinlan asserted his authority as guardian, and had Ms. Quinlan's respirator removed. ${ }^{66}$

Following the Quinlan court's lead, other courts faced with the issue have unanimously concluded that the right to refuse medical treatment "would be an einpty right if one who is incoinpetent were not granted the right of a colnpetent counterpart to exercise his rights."67

\section{The Right Of Incompetent Patients Whose Wishes Cannot Be Known To Refuse Medical Treatment}

Notwithstanding the judicial extension of the right to refuse life-sustaining medical treatment to incompetent patients, courts are still struggling to articulate a workable and ethically acceptable standard to be applied to decisions involving patients whose wishes cannot be known. Courts have developed, and continue to fine-tune, two standards to guide surrogate decisionmaking: "substituted judgment" and "best interests." While a "best interests" test is clearly the apphicable standard for incompetent patients whose wishes are not known, ${ }^{68}$ and inany courts have

63. Id. at $41,355 \mathrm{~A} .2 \mathrm{~d}$ at 664 .

64. Id. This notion of a surrogate implementing an incompetent patient's constitutional right to privacy (or common law right to bodily imtegrity) by deciding as the patient would have decided has come to be called "substituted judgment" or the subjective test. For a discussion concerning this standard of surrogate decisionmaking, see infra notes 69-93 and accompanying text. Ironically, the New Jersey Supreme Court in Quinlan embraced this "substituted judgment" standard despite the court's own concession that available evidence of what Ms. Quinlan would have wanted was noticeably insufficient. For discussion of this discrepancy, see infra notes 79-82.

65. 70 N.J. at 55,355 A.2d at 671 .

66. Ms. Quinlan survived the removal of the respirator for over nine years. On June 11, 1985, she died of respiratory failure brought on by acute pneumomia. See N.Y. Times, June 12, 1985, at A1, col. 2.

67. In re Barry, 445 So. 2d 365, 370 (Fla. Dist. Ct. App. 1984); see also, e.g., In re Severns, 421 A.2d 1334, 1347 (Del. 1980) (quoting In re Eichner, 73 A.D.2d 431, 470, 426 N.Y.S.2d 517, 546 (1981): "[T]o deny the exercise because the patient is unconscious would be to deny the right"); In re Gardner, 534 A.2d 947, 950-52 (Me. 1987) (right to self-determination impliedly extended to incompetent patients); In re Guardianship of Grant, 109 Wash. 2d 545, 552, 747 P.2d 445, 449 (1987) ("An incompetent's right to refuse treatment should be equal to a competent's right to do so.").

68. After all, the "substituted judgment" test sinply einpowers the surrogate decisionmaker to decide what the patient, if competent, would have thought to be in her own best interests. 
embraced this standard, the criteria for determining the true "best interests" of a patient whose wishes are not known have proven elusive.

\section{The "Substituted Judgment" Standard: Quinlan and Its Progeny}

Under the "substituted judgment" standard, the guardian "attempt[s] to reach the decision that the imcapacitated person would make if he or she were able to choose." 69 Two assumptions underlie this standard: (1) an incompetent person possesses the same rights as one who is competent, mcluding the right to forego life-sustaining treatment; and (2) a surrogate may exercise these rights for the incompetent based on a personal judgment regarding what the patient would have chosen if competent. ${ }^{70}$

In making this judgment, the surrogate either follows explicit directives made by the patient while competent or, absent explicit directions, applies the patient's known preferences and values. ${ }^{71}$ The "substituted judgment" test is satisfied "when it is clear that the particular patient would have refused the treatinent under the circumstances involved."72 In order to determine if the now incompetent patient's wishes are "clear," the surrogate must evaluate any indications the patient has previously given in terms of their remoteness, consistency, thoughtfulness, maturity, and specificity. ${ }^{73}$ For example, the existence of an advance directive $^{74}$ has the most probative value; it plaiuly reflects a prior competent choice. ${ }^{75}$ Courts have also recognized other indications of prior

69. PResidenT's CoMm'N, supra note 6, at 132.

70. See Note, Substituted Judgement in Medical Decisionmaking for Incompetent Persons: In re Storar, 1982 WIS. L. REv. 1173, 1192 (authored by Suzanne E. Williams). These assumptions were first articulated by the Quinlan court. In re Quinlan, 70 N.J. 10, 41, 355 A.2d 647, 664, cert. denied 429 U.S. 922 (1976).

71. See HASTINGS' GUIDELINES, supra note 6, at 28.

72. In re Conroy, 98 N.J. $321,360,486$ A.2d 1209, 1229.

73. Id. at $362-63,486 \mathrm{~A} .2 \mathrm{~d}$ at 1230 .

74. An advance directive is a document allowing a person to give directions about future medical care, or to designate who should make medical decisions if he or she should lose decisionmaking capacity. There are two types of advance directives. In a treatment directive, such as a "living will," a person can indicate those treatments, including lifesustaining treatment, in particular, that the person wishes to receive or forgo [sic] should he or she be $\mathrm{m}$ stated medical conditions (such as irreversible unconsciousness, severe and irreversible dementia, or termmal illness) and lack decisionmaking capacity. In that document, or in a separate proxy directive, a person can identify a surrogate to make treatment decisions should he or she be unable to make such decisions.

HASTINGS' Guidelines, supra note 20, at 78.

For discussion of statutory recognition of treatment and proxy directives, see supra notes $48-51$ and accompanying text.

75. See Conroy, 98 N.J. at 362,486 A.2d at 1230 ("dealing with the matter in advance in some sort of thoughtful and explicit way is best for all concerned"); see also John F. Kennedy Memorial Hosp. v. Bludworth, 452 So. 2d 921, 922 (Fla. 1984) ("living will" accepted as persuasive evidence of an incompetent person's intention); In re Peter, 108 N.J. 365, 378, 529 A.2d 419, 426 (1987) (durable power of attorney authorized surrogate to make all medical decisions on patient's behalf). 
competent preferences as probative, such as religious beliefs, ${ }^{76}$ reactions voiced regarding medical treatinent administered to others who were similarly situated, ${ }^{77}$ and oral directives given to a family inember, friend, or health care provider. ${ }^{78}$

Because it attempts to rephicate what the patient would choose if she could speak, the "substituted judgment" standard is most useful when a patient has expressed her wishes while competent. Conversely, if there is no rehable evidence of the patient's preferences, the "substituted judgment" standard provides hittle or no guidance to the surrogate decisionmaker.

Despite the standard's obviously limited application, courts have used it even when there was little or no rehable evidence regarding the patient's wishes. For example, the New Jersey Supreine Court in Quinlan embraced a "substituted judgment" standard" ${ }^{79}$ despite the court's own concession that evidence of what Ms. Quinlan would have wanted was lackirig. ${ }^{80}$ Since access to Ms. Quinlan's actual wishes was impossible, ${ }^{81}$ the court's suggested decisionmaking process is not a valid applica-

76. E.g., In re Quinlan, 70 N.J. 10, 30-31, 355 A.2d 647, 658-62, cert. denied 429 U.S. 922 (1967) (although explicitly rejecting an independent parental right of religious freedom, the court did evaluate the religious beliefs of the patient to determine her preferences concerning life-sustaining medical treatment); In re Storar, 52 N.Y.2d 363, 379, 420 N.E.2d 64, 72, 438 N.Y.S.2d 266, 274, cert. denied, 454 U.S. 858 (1981).

77. Discussion among family and friends concerning the plight of Karen Ann Quinlan-a national news event-was snbsequently used by courts to determme the prior competent preferences of now incompetent patients. E.g., Brophy v. New England Sinai Hosp., 398 Mass. 417, 428, 497 N.E.2d 626, 631-32 (1986) (relying on Brophy's statements made prior to his illness that he would choose to forego life-sustaining nuedical treatnent); Storar, 52 N.Y.2d at 371-72, 379-80, 420 N.E.2d at $68,72,438$ N.Y.S.2d at 270,274 (utilizing testiniony indicating that, when competent, an 83-yearold patient had explicitly expressed to others his conclusion that he did not want to be nuaintained in a vegetative condition by use of a respirator).

78. E.g., In re Severns, 425 A.2d 156, 158 (Del. Ch. 1980) (patient's expression to her husband when competent that she did not want to be kept alive in a persistent vegetative state but would like to be allowed to die with dignity); In re Gardner, 534 A.2d 947, 949 (Me. 1987) (permitting discontimuation of life-sustaining procedures for a 23 year-old man in a persistent vegetative state who, prior to his accident, had expressed his desire not to receive such treatment).

79. 70 N.J. at 41,355 A. $2 \mathrm{~d}$ at 664 ("The only practical way to prevent destruction of the right [to privacy] is to permit the guardian and family of Karen to render their best judgment . . . as to whether she would exercise it in these circumstances.")

80. Id. at $21,41,355$ A.2d at 653,664 . The New Jersey Supreme Court later admitted it had erred "to disregard evidence of statements that Ms. Quinlan made to friends concerning artificial prolongation of the lives of others who were terminally ill." In re Conroy, 98 N.J. 321, 362, 486 A.2d 1209, 1230.

81. Although this was so, the court attempted to identify and implenient Ms. Quinlan's competent wishes by fictionalizing the facts of the case:

We have no doubt, in these unhappy circunistances, that if Karen were herself miraculously lucid for an interval (not altering the existing prognosis of the condition to which she would soon return) and perccptive of her irreversible condition, she could effectively decide upon discontinuance of the life-support apparatus, even if it meant the prospect of natural death.

Quinlan, 70 N.J. at 39,355 A.2d at 663-64 (enuphasis added). 
tion of "substituted judgment."82

In another misapplication of the "substituted judgment" standard, the Massachusetts Supreme Judicial Court apphed the test to a patient who had been incompetent since birth. ${ }^{83}$ In that case, which was widely criticized, ${ }^{84}$ the court reviewed a probate court's decision not to administer chemotherapy to a sixty-seven year-old man suffering from leukemia who had been mentally mcompetent and unable to communicate verbally from birth. ${ }^{85}$ The court recognized the difficulty in applying the substituted judgment standard in such a situation, ${ }^{86}$ but nonetheless elected to use it. That such a procedure converted the substituted judgment into an objective test did not go unnoticed. In a footnote, the court approvingly cited the position that surrogates should "act with respect to the preferences a reasonable, competent person in the mcompetent's situation would have."87 Obviously, such an analysis ignores the true purpose of the standard-to effectuate the specific patient's actual desires, not the speculative desires of a non-existent reasonable person.

Other courts have explicitly recognized that "substituted judgment" is a fiction when evidence of the patient's wishes is unavailable. For

82. After Quinlan, the New Jersey Supreme Court embraced a more expansive notion of "substituted judgment," in which stated preferences were recognized as appropriate aids in determining what course of treatment a patient would have wished to pursue. See Conroy, 98 N.J. at 362,486 A.2d at 1230 . Soine coininentators contend that a mere stated preference lacks the inoral weight of a prior choice (einbodied in an advance directive) and argue that only dehiberate choices should be accorded probative value as indicative of the once competent patient's wishes. See, e.g., Buchanan \& Brock, Deciding for Others, 64 MilbaNk MEM. Fund Q. 17, 71-72 (Supp. II, 1986).

83. Superintendent of Belchertown State School v. Saikewicz, 373 Mass. 728, 370 N.E.2d 417 (1977).

84. See, e.g., Weber, Substituted Judgment Doctrine: A Critical Analysis, 1 Issues iN L. \& MED. 131, 145-46 (1985) (footnotes ornitted):

When the incoinpetent not only leaves no evidence of his intent, but never even could formulate legally effective wishes, as in Saikewicz, the court inust struggle with a complete absence of guiding factors. In such circuinstances, efforts to ascertain the incompetent's intent are dooined from the start: courts cannot attribute a legally conclusive intent to an incoinpetent without deriving that intent from sources external to the incoinpetent. Substituted judgment requires the court to piece together testimony from relatives and acquaintances to construct a persona who then represents and decides for the incompetent. The entire endeavor appears more an exercise in fietional characterization than an enhanceinent of rights.

See also Note, Live or Let Die; Who Decides an Incompetent's Fate? In re Storar and In re Eichner, 1982 B.Y.U. L. REv. 387, 392-93 (authored by Kevin W. Bates) (reinarking that the substituted judgment doctrine permits decisionmakers to shift responsibility for a patient's death from theinselves to the patient by requiring the decisionunakers to pretend they are deciding what the incompetent patient would do); Note, Equality for the Elderly Incompetent: A Proposal for Dignified Death, 39 STAN. L. REv. 689, 714 (1987) (authored by Tracy L. Merritt) (stating that "substituted judgment" cannot preserve the patient's autonoiny without reliable evidence as to the patient's intent).

85. 373 Mass. at $729-31,370$ N.E.2d at $419-20$.

86. Id. at 751,370 N.E.2d at $430-31$.

87. Id. at $750-51$ n.15, 370 N.E.2d at 430 n.15 (citing Robertson, Organ Donations by Incompetents and the Substituted Judgment Doctrine, 76 CoLUM. L. REV. 48, 63 (1976) (quoting J. Rawls, A Theory of Justice 209 (1971))). 
example, im In re Storar, ${ }^{88}$ a profoundly retarded man suffering from bladder cancer required constant blood transfusions to survive. ${ }^{89}$ Since Mr. Storar "was always totally incapable of understanding or making a reasoned decision about medical treatment,"90 the court recognized the futility of attempting to determine his wishes, ${ }^{91}$ and rejected any attempt at "substituted judgment." Instead, it reasoned that its decision must rest on principles different from those applicable to patients who had once been competent. ${ }^{92}$ Unfortunately, the court never specified what these principles were and, instead, simply held that the patient should continue to receive blood transfusions. ${ }^{93}$

Thus, although it recognized the need to do so, the Storar court declined to articulate any principles governing surrogate decisionmaking for an incompetent patient whose wishes cannot be known. Only with the Conroy decision did any state's highest court atteinpt to outline standards for this particular class of patient.

\section{The "Best Interests" Standard: Conroy and Its Progeny}

The New Jersey Supreme Court in In re Conroy ${ }^{94}$ outlined exhaustive requirements for deciding to terminate or withhold medical treatment for an imcompetent patient. ${ }^{95}$ Expanding upon, refiming, and clarifying its holding in Quinlan, the New Jersey Supreme Court in Conroy again "set[ ] the benchmark in this area of the law."96

This landmark decision involved Claire Conroy, an eighty-four year-old bedridden nursmg home patient with serious irreversible physical and mental impairments and a limited life expectancy. ${ }^{97}$ Ms. Con-

88. 52 N.Y.2d 363, 420 N.E.2d 64, 438 N.Y.S.2d 266, cert. denied, 454 U.S. 858 (1981).

89. Id. at 374,420 N.E.2d at 69,438 N.Y.S.2d at 271.

90. Id. at 380,420 N.E.2d at 72,438 N.Y.S.2d at 275 (emphasis added).

91. Id. at 380,420 N.E.2d at 72-73, 438 N.Y.S.2d at $274-75$. The court noted that such an inquiry "would be similar to asking whether 'if it snowed all summer, would it be winter?' " Id. at 380,420 N.E.2d at $72-73,438$ N.Y.S.2d at 275.

92. Id. at 380,420 N.E.2d at 73,438 N.Y.S. $2 \mathrm{~d}$ at 275.

93. Id. at 381,420 N.E.2d at 73,438 N.Y.S.2d at 275.

94. 98 N.J. 321,486 A.2d 1209 (1985).

95. Id. at $360-68,486 \mathrm{~A} .2 \mathrm{~d}$ at $1229-33$.

96. Strasser, The Conroy Case: An Overview, in By No Extraordinary Means: The Choice to Forgo Life-Sustaining Food AND WATER 245, 247 (J. Lynn ed. 1986).

97. Conroy, 98 N.J. at 335, 486 A.2d at 1216; see generally In re Claire C. Conroy: $A$ Case Study, in By No Extraordinary MEans: The Choice to Forgo LifE-Sustaining Food and WATER, supra note 96 , at 227-66. The court limited its decision to nursing home residents because they are governed by New Jersey statutes that do not apply to elderly persons in other settings. 98 N.J. at 342 n.1, 486 A.2d at 1219 n.1. Moreover, the Conroy court carefully restricted its holding to elderly patients like Claire Conroy who suffer from serious and permanent mental and physical impairments, who will probably die within one year even with treatment and who, though formerly competent, are now incompetent to make decisions about their life-sustaining treatment and are unlikely to regain such competence. Id. at 342,486 A.2d at 1219-20.

Other courts commanded national attention by quickly expanding Conroy to other classes of 
roy's guardian, who was also her nephew and only surviving relative, sought permission to remove a nasogastric feeding tube, ${ }^{98}$ because Ms. Conroy was hopelessly ill with no possibility of returning to cognitive life. ${ }^{99}$ Because the trial court found that Ms. Conroy's "intellectual functioning ha[d] been permanently reduced to an extremely primitive level," 100 and that her life had become "impossibly and permanently burdensome for her,"101 it permitted removal of the feeding tube. ${ }^{102}$

While an appeal by the guardian ad litem ${ }^{103}$ was pending, Ms. Conroy died with the nasogastric tube in place. ${ }^{104}$ Though her death rendered moot the issues on appeal, the appellate court, acknowledging the substantial importance of the issues presented, ${ }^{105}$ proceeded to decide the case on the merits and reversed the trial court on two alternative grounds. First, the court held that "the right to terminate life-sustaining treatment based on a guardian's substituted judginent should be limited to incurable and terminally ill patients who are brain dead, irreversibly comatose or vegetative and who would gain no medical benefit from continued treatment."106 Second, the court held that "when nutrition will contmue the life of a patient who is not comatose, brain dead or vegetative, and whose death is not irreversibly imminent, its discontinuance cannot be permitted on the theory of the patient's right to privacy or, indeed, on any other basis." 107

patients, such as permanently vegetative but not terminally ill patients, see Brophy v. New England Sinai Hosp., 398 Mass. 417, 497 N.E.2d 626 (1986), and competent, non-elderly and non-terminally ill patients. See Bouvia v. Superior Court, 179 Cal. App. 3d 1127, 225 Cal. Rptr. 247 (1986).

In a trilogy of cases decided on June 24, 1987, the New Jersey Supreme Court itself expanded Conroy to apply to a competent patient at home, and two nursing home patients in persistent vegetative states, one an elderly patient with a hife expectancy of nore than one year, and the other a non-elderly patient. See In re Jobes, 108 N.J. 394, 529 A.2d 434 (1987) (non-elderly nursing home patient); In re Peter, 108 N.J. 365, 529 A.2d 419 (1987) (elderly nursing hoine patient with life expectancy of more than one year); In re Farrell, 108 N.J. 335, 529 A.2d 404 (1987) (competent patient at home). Because of their ages, places of residence, and medical conditions, none of the patients in these cases fell withm the factual pattern of either of the court's seminal decisions, Quinlan or Conroy. See Farrell, 108 N.J. at 341, 529 A.2d at 406-07.

98. Conroy, 98 N.J. at 335,486 A.2d at 1216.

99. Id. at $339,486 \mathrm{~A} .2 \mathrm{~d}$ at 1218 .

100. In re Conroy, 188 N.J. Super. 523, 529, 457 A.2d 1232, 1236 (Ch. Div.), rev'd, 190 N.J. Super. 453, 464 A.2d 303 (App. Div. 1983), rev'd, 98 N.J. 321, 486 A.2d 1209 (1985).

101. 188 N.J. Super. at 529,457 A.2d at 1236.

102. Id. at $532,457 \mathrm{~A} .2 \mathrm{~d}$ at 1237 .

103. A guardian ad litem is an attomey appointed by the court to represent an imfant or incompetent in proceedings to which he or she is a party. See BLACK's LAW DictionaRY 635 (5th ed. 1979). New Jersey case law does not specify the role of the guardian ad litem in any judicial evaluation concerning the decision to forego hife-sustaiming treatment. See DeLaney, The Role of the Guardian ad Litem, in By No Extraordinary MEANS: The ChOICE To Forgo LiFESUSTAINING FOOD AND WATER, supra note 96, at 249.

104. Conroy, 98 N.J. at 341, 486 A.2d at 1219.

105. Conroy, 190 N.J. Super. 453 at $458-60,464$ A.2d 303 at 305-06.

106. 190 N.J. Super. at 466,464 A.2d at 310.

107. Id. at $469-70,464 \mathrm{~A} .2 \mathrm{~d}$ at 312 (emphasis added). 
The New Jersey Supreme Court reversed the appellate court, ${ }^{108}$ rejectimg the appellate court's focus on the type of treatment involved. ${ }^{109}$ The court redefined the existing legal categories by proposing a new articulation of the Quinlan "substituted judgment" standard, which it termed the "subjective" standard, ${ }^{110}$ and by advancing two forms of a "best interests" standard, which it termed the "limited-objective" and the "pure-objective" tests. ${ }^{111}$ Noting that "it is naive to pretend that the right to self-determination serves as the basis for substituted decisionmaking"112 absent adequate proof of the patient's wishes, the Conroy court created these two objective tests to address precisely the issue left unanswered by the court in In re Storar ${ }^{113}$-how to determine if treatment may be withheld when there is no clear and convincing proof of the patient's attitude toward such treatment. ${ }^{114}$

The "subjective" test is met "when it is clear that the particular patient would have refused the treatment under the circumstances involved."115 The "limited-objective" test requires "some trustworthy evidence that the patient would have refused the treatment [and it unust be] clear that the burdens of the patient's continued hife with the treatinent outweigh the benefits of that life for him."

108. In re Conroy, 98 N.J. 321, 486 A.2d 1209 (1985)

109. Id. at 369, 486 A.2d at 1233; cf. Barber v. Superior Court, 147 Cal. App. 3d, 1006, 1018 . 19, $175 \mathrm{Cal}$. Rptr. 484, 491 (1983) (rejecting the ordinary/extraordinary treatment distinction in favor of the proportionate benefit/burden approach).

110. 98 N.J. at 360,486 A.2d at 1229 .

111. Id. at 365, 486 A.2d at 1231-32. Several post-Conroy commentators have suggested similar tests. See, e.g., Hastings' GuideliNes, supra note 6, at 27-29 (suggesting that one of three standards be applied depending on the streugth of the evidence of the patient's preferences: (1) the patient's explicit directives; (2) the patient's preferences and values; or (3) a reasonable person's preferences and values in the patient's circumstances); Lynn, Elderly Residents of Long-Term Care Facilities, in By No ExTraordinary MEANS: The Choice to Forgo Life-Sustaining Food AND WATER, supra note 96, at 163, 169 (suggesting that a "continuum" exists between the use of objective and subjective criteria depending on the reliability and extent of the evidence).

112. Conroy, 98 N.J. at 364,486 A.2d at 1231 .

113. 52 N.Y.2d 363, 420 N.E.2d 64, 438 N.Y.S.2d 266, cert. denied, 454 U.S. 858 (1981); see supra notes 88-93 and accompanying text for a discussion of Storar.

114. The Conroy focus on best interests is fully consistent with traditional guardianship principles prescribing that a guardian occupies a trust or fiduciary relationship toward an incoinpetent ward. See Capron, The Authority of Others to Decide About Biomedical Interventions with Incompetents, in WHO SPEAKS FOR THE CHILD? 121-22 (W. Gaylin \& R. Macklin eds, 1982).

115. Conroy, 98 N.J. at $360-61,486$ A.2d at 1229. The court continued: "The standard wc are enunciating is a subjective one.... The question is not what a reasonable or average person would have chosen to do under the circumstances but what the particular patient would have done if able to choose for himself." Id. at 360-61, 486 A.2d at 1229 (emphasis added).

116. Conroy, 98 N.J at 365,486 A.2d at 1232. The court explained:

By this we mean that the patient is suffering, and will continue to suffer throughout the expected duration of his life, unavoidable pain, and that the net burdens of his prolonged life (the pain and suffering of his life with the treatment less the amount and duration of pain that the patient would likely experience if the treatment were withdrawn) markedly outweigh any physical pleasure, enotional enjoyment, or intellectual satisfaction that the patient may still be able to derive from life. 
thy evidence of the patient's wishes, the surrogate's decision must pass the "pure-objective" test. To meet this standard, the surrogate must demonstrate the existence of two conditions: (1) the burdens of initiating or continuing life-sustaining medical treatment "clearly and markedly" outweigh the benefits, and (2) the "recurring, unavoidable and severe pain of the patient's life with the treatınent should be such that the effect of administering life-sustaining treatment would be inhumane."117 As a safeguard, the Conroy court noted that "[w] hen evidence of a person's wishes or physical or mental condition is equivocal, it is best to err, if at all, in favor of preserving life."118

\section{II}

The Failure of Courts to Articulate AN ADMINISTRABle STANDARd APPLICABLE TO INCOMPETENT PATIENTS WhOSE Wishes CANNOT BE KNOWN

In cases where the patient has been incompetent since birth or when no one is sufficiently familiar with the patient to be able to know what the patient would have decided, ${ }^{119}$ the Conroy "pure-objective" test requires the surrogate decisionmaker to assess what medical treatment would be in the patient's best interests as determined by certain objective criteria. ${ }^{120}$ To identify these criteria and to convince the legal, ethical, and inedical establishments of their objectivity remains a crucial unresolved legal issue. The continued viability of the "pure-objective" test is threatened by its elusiveness and by the failure of the judiciary to define socially acceptable "best interests." This task cannot be accomplished, however, until these estabhishments relinquish their current focus on the type of treatinent mvolved and look instead to the needs of the patient.

\section{A. The Conroy Standard and Its Emphasis on Pain}

The Conroy court itself specified "recurring, unavoidable and severe pain"121 as the prerequisite to termination of life-sustaining treatment. ${ }^{122}$

Id. at 365,486 A.2d at 1232 .

117. Id. at $366,486 \mathrm{~A} .2 \mathrm{~d}$ at 1232 .

118. Id. at $368,486 \mathrm{~A} .2 \mathrm{~d}$ at 1233 .

119. See, eg., In re Jobes, 108 N.J. 394, 431 n.2, 529 A.2d 434, 453 n.2 (1987) (Handler, J., concurring) (noting that the "difficult extreme case" would be one "where there is no basis for deciding what choice the patient would have made") (citing In re Hamlin, 102 Wash. 2d 810, 689 P.2d 1372 (1984)); see also In re L.H.R., 253 Ga. 439, 321 S.E.2d 716 (1984); Superintendent of Belchertown v. Saikewicz, 373 Mass. 728, 370 N.E.2d 417 (1977); In re Storar, 52 N.Y.2d 363, 420 N.E.2d 64, 438 N.Y.S.2d 266, cert. denied, 454 U.S. 858 (1981).

120. 98 N.J. at $366-69,486$ A.2d at $1232-33$.

121. Id. at 366, $486 \mathrm{~A} .2 \mathrm{~d}$ at 1232 .

122. Some commentators have argued that the Conroy court did not really intend to identify the presence or absence of physical pain as the sole criterion for terminal decisionmaking. See, e.g., N. 
An exclusive focus on pain, however, devalues other important ideals regarding life and death. Justice Handler pointedly criticized the Conroy majority for ignoring "a whole cluster of other human values that have a proper place in the subtle weighing that will ultimately deternnine how life should end." 123

In addition, the Conroy standard may be largely unenforceable for two inedical reasons. First, given the current status of inedical technology and manageinent of terminal disease, pain is not an operative factor in many cases. ${ }^{124}$ "[P]resently available drugs and techıriques allow pain to be reduced to a level acceptable to virtually every patient, usually without unacceptable sedation."125 Second, even if pain is present, health care providers inay be unable to assess the degree of pain experienced by a patient too incoinpetent to communicate with current neurological technology..$^{126}$

For these reasons, the Conroy "physical pain test" may absolutely bar the withdrawal of life-support in many cases. In Conroy itself, the court did not rule on the best interests of Ms. Conroy; ${ }^{127}$ had she still been alive, the court would have remanded the case for additional inedical evidence pertaining to her pain and suffering. ${ }^{128}$ Without this evidence, the court would not have endorsed reinoval of the feeding tube as being in Ms. Conroy's best interests. ${ }^{129}$

Most courts since Conroy have rejected an exclusive focus on pain in determining a patient's best interests. ${ }^{130}$ For instance, several courts ${ }^{131}$

CANTOR, supra note 20, at 71; cf. In re Visbeck, 210 N.J. Super. 527, 538-539, 510 A.2d 125, 131 (N.J. Super. Ch. Div. 1986) ("it becomes clear that treatment may not be withheld or withdrawn from an incompetent patient under Conroy. . . unless the patient is suffering from recurring, unavoidable and severe pain").

123. Conroy, 98 N.J. at 394, 486 A.2d at 1247 (Handler, J., concurring in part and dissenting in part).

124. Saunders, Current Views on Pain Relief and Terminal Care, in THE Therapy of PalN 215 (Swerdlow ed. 1981) (a hospice reports complete control of pain in over $99 \%$ of its dying patients).

125. PResident's CoMm'N, supra note 6, at 50-51.

126. See generally id. at 277-95 (discussing ways to control dying patients' symptoms); THE Management of TeRminal Disease (Saunders ed. 1978) (cited in Conroy, 98 N.J. at 394, 486 A.2d at 1247 (Handler, J., concurring in part and dissenting in part)).

127. Conroy, 98 N.J. at $367-68,486$ A.2d at 1233.

128. 98 N.J. at $386-87,486$ A.2d at 1243 .

129. Id. at $386-87,486 \mathrm{~A} .2 \mathrm{~d}$ at 1243.

130. See, eg., In re Visbeck, 210 N.J. Super. 527, 538-39, 510 A.2d 125, 131 (N.J. Super. Ch. Div. 1986) ("I must say that $I$ think [the Conroy focus on pain] is wrong because it manifests a much too limited view of what is at stake in these cases."); cf. Conroy, 98 N.J. at 397-98, 486 A.2d at 1249 (Handler, J., concurring in part and dissenting in part) (rejecting the majority's exclusive focus on patient pain and proposing instead a more expansive standard:

[T] he standard should consist of an array of factors to be medically established and then evaluated by the decision-maker both singly and collectively to reach a balance that will justify the determination whether to withdraw or to continue life-prolonging treatment. ... Several important criteria bear on this critical determination. The person should be terminally ill and facing imminent death. There should also be present the permanent loss 
and at least one legislature ${ }^{132}$ have endorsed a more expansive standard suggested in the President's Commission Report: "In assessing whether a procedure or course of treatment would be in a patient's best interests, the surrogate must take imto account such factors as the relief of suffering, the preservation or restoration of functioning, and the quahty as well as the extent of life sustained." 133

\section{B. The Ordinary/Extraordinary Distinction and the Focus on Treatment}

As is apparent from the foregoing discussion of potential standards, where there is no basis for predicting what decision an imcompetent patient whose wishes are unknown would have made, courts have yet to find acceptable criteria on which to base treatment decisions. ${ }^{134}$ The ordinary/extraordinary distimction, often used to distinguish medical treatments that may ethically be withheld or withdrawn froin those that may not, contributes to this continued judicial uncertainty.

The distinction between "ordinary" and "extraordmary" means of treatment ${ }^{135}$ traditionally has been used to determine which life-sustaining procedures must be used and how long their use must be main-

of conscious thought processes in the form of a comatose state or profound unconsciousness. Further, there should be the irreparable failure of at least one major and essential bodily organ or system.

131. See, e.g., In re Fleming, 154 Ariz. 207, 222, 741 P.2d 674, 688-89 (1987); Visbeck, 210 N.J. Super. at 539-40, 510 A.2d at 131-32.

132. As defined by a New York statute:

"Best interests" means promoting personal well-being by the assessment of the risks, benefits and alternatives to the patient of a proposed major medical treatment, taking into account factors including the retief of suffering, the preservation or restoration of functioning, improvement in the quality of the patient's life with and without the proposed major medical treatment and consistency with the personal beliefs and values known to be held by the patient.

N.Y. MENTAL HYG. LAW $\S 80.03$ (McKinney Supp. 1988). For a decision interpreting this statute, see In re Beth Israel Medical Center, 136 Misc. 2d 931, 938-39, 519 N.Y.S.2d 511, 516-18 (Sup. Ct. 1987).

133. PREsIDENT's COMM"N, supra note 6, at 135. "Quality of life" here refers to "the value that the continuation of life has for the patient" and not "the value that others find in the continuation of the patient's life." Id. at 135 n.43.

134. As Justice Handler noted in his concurring opinion in Jobes, "[i]n the absence of legitimate direction, the courts will have to find some criteria, some values upon which to authorize or refuse authorization for treatment decisions in contexts where we have no basis for predicting what decision an imcompetent patient would have wanted made." In re Jobes, 108 N.J. 394, 431, 529 A.2d 434, 453 (1987) (Handler, J., concurring).

135. Ordinary ineans of preserving life are all medicines, treatments, and operations, which offer a reasonable hope of benefit for the patient and which can be obtained and used without excessive expense, pain, or other inconverience.

Extraordinary means of preserving life ... [are] all medicines, treatments, and operations, which cannot be obtained or used without excessive expense, pain, or other inconvenience, or which, if used would not offer a reasonable hope of benefit.

G. Kelly, Medico-Moral Problems 129 (1958); see also President's Comm'n, supra note 6, at 82-89. 
tained. ${ }^{136}$ It has been a common presupposition that extraordinary means of treatment can be discontinued, while ordinary means inust be maintained. This distinction focuses on the "state of the art of any particular medical intervention"137 and not on the patient.

Prior to 1985, a number of courts had relied on the ordinary/ extraordinary distinction. However, in 1985 the Conroy court systematically examined and rejected the role of the traditional ethical distinction between "ordinary" treatment which is required and "extraordinary" treatment which is optional. ${ }^{138}$ The Conroy opinion inarked the first rejection of the ordinary/extraordinary distinction by a state's highest court. In its place, the Conroy court adopted a proportionate/disproportionate treatment standard developed by a California appellate court. ${ }^{139}$ Under this new standard, courts determine whether the proposed treatment is proportionate or disproportionate to the benefits to be gained and the burdens caused for the particular patient involved. The focus of this determination, therefore, is on the patient, not the treatment.

Despite general acceptance of this new standard, a few coinmentators $^{140}$ continue to argue against the rejection of the ordinary/extraordinary distinction, contending that abandonment of this approach will mean abandonment of objective considerations-such as the patient's medical condition or human circumstances-and will make the decision

136. Various courts have predicated their decisions that life-sustaining treatment could be discontinued in part on the ground that the specific treatinent in question was "extraordinary." See, e.g., John F. Kennedy Memorial Hosp. v. Bludworth, 452 So. 2d 921, 926 (Fla. 1984); Superintendent of Belchertown State School v. Saikewicz, 373 Mass. 728, 731, 370 N.E.2d 417, 424 (1977); In re Quinlan, 70 N.J. 10, 48, 355 A.2d 647, 667-68, cert. denied, 429 U.S. 922 (1976).

137. Jonsen, What is Extraordinary Life Support?, 141 W. J. MED., Sept. 1984, at 358, 361 (attacking the ordinary/extraordinary distinction using the example of blood transfusions: considered extraordinary in the 1930 s, blood transfusions are now an ordinary means of care in conteinporary inedicine).

138. In re Conroy, 98 N.J. 321, 370-72, 486 A.2d 1209, 1234-35 (1985) (citing PresidenT's CoMm'N, supra note 6, at 83 ("defining and applying a distimction between ordinary and extraordinary treatment is both difficult and controversial and ean lead to imconsistent results, which makes the terms of questionable value in the formulation of public policy in this area")).

139. Barber v. Superior Court, 147 Cal. App. 3d 1006, 1018-19, 195 Cal. Rptr. 484, 491 (1983) ("The use of these terms [ordinary/extraordinary] begs the question. A more rational approach involves the determination of whether the proposed treatinent is proportionate or disproportionate in terms of the benefits to be gained versus the burdens caused.").

Other states' highest courts have followed the Conroy lead on this issue. See, e.g., Brophy v. New England Sinai Hosp., 398 Mass. 417, 437, 497 N.E.2d 626, 637 (1986) ("While we believe that the distinction between extraordinary and ordinary care is a factor to be considered, the use of such a distinction as the sole, or major, factor of decision tends . . . to create a distinction without meaning."); In re Grant, 109 Wash. 2d 545, 564, 747 P.2d 445, 454 (1987) (quoting with approval the A.M.A. STATEMENT, supra note 42 , at 13 , for the proposition that "[i]n treating a terminally ill or irreversibly coinatose patient, the physician should determine whether the benefits of treatment outweigh its burdens.").

140. See, eg., Smith, Judeo-Christian Teaching on Euthanasia: Definitions, Distinctions and Decisions, 54 LiNACRE Q., Feb. 1987, at 27. 
too subjective. Proponents of this distinction insist that it ensures moral objectivity and effectively precludes any subjective "quality of life" considerations, due to its exclusive focus on the ordinariness or extraordinariness of available medical technology and not on the life of the patient. ${ }^{141}$

These arguments are unpersuasive because they overestimate the objectivity of the ordinary/extraordinary distinction and devalue the "objective" component of a benefits/burdens analysis. In addition, despite protestations to the contrary, a "quality of life" element is always present in the very definition of extraordinary means. ${ }^{142}$ In fact, one could argue that the ordinary/extraordinary terminology actually disguises the quality of life component so often present in the treatment decisions made by coinpetent dying patients, and by surrogates on behalf of incompetent dying and nondying patients. ${ }^{143}$

The traditional ordinary/extraordinary distinction ultimately fails because its focus is misplaced. The distinction was an attempt to create a morally sound haven in technological categorization. Althougl it is comforting to assert apodictically that to forego a particular medical intervention is morally licit because the prospective means are "extraordinary," the exclusive focus on medical technology fails to consider the plight of the particular patient. However understandable this desire for moral certitude may be, any decision to forego life-sustaining treatment must evaluate the potential benefits and burdens of the specific treatment for that particular patient. Evaluating benefits and burdens rather than labelling treatinents "ordinary" or "extraordinary" considers each ethical decision to be unique and, therefore, respects an autonomous agent's right to self-governance. ${ }^{144}$

The special significance accorded the decision to forego artificial nutrition and lydration ${ }^{145}$ relative to other medical procedures hints at

141. "[The] designation ordinary/extraordinary is predicated of the means, NOT of the life of the patient ...."). Id. at 30 (emphasis in original).

142. See, e.g., McCormick, The Quality of Life, The Sanctity of Life, 8 HASTINGS CENTER REP., Feb. 1978, at 32-33.

143. Id. at 37.

144. An individual's autonony is not unlimited. The balancing test in Quinlan, for example, described a patient's right to refuse inedical treatment in a waxing and waning inetaphor, suggesting that in the equation were only the individual's right of self-determination and the State's legitimate interest in preventing suicide: "The State's interest contra weakens and the individual's right to privacy grows as the degree of bodily invasion increases, and the prognosis dims. Ultimately there coines a point at which the individual's rights overcoune the State interest." In re Quinlan, 70 N.J. 10, 41, 355 A.2d 647, 664, cert. denied, 429 U.S. 422 (1970); see generally T. BEAUchaMP \& J. Childress, Principles of Biomedical Ethics 62 (2d ed. 1983) (asserting centrality of patient autonoiny in inedical decisionmaking).

145. The inedical interventions that provide food and fluids to patients nnable to feed themselves or to swallow spoon feedings are of two basic forms: (1) medical enteral procedures or (2) parenteral nutritional procedures. 
the continued, though greatly diminished, vitality of the ordinary/ extraordinary distinction. The overwhelıning judicial consensus to treat nutrition and hydration no differently than other life-sustaining medical treatment ${ }^{146}$ is not umiversally shared by state legislatures. Specifically, a number of living-will statutes exphicitly exclude nutrition and hydration from the category of life-prolonging treatment that can be withdrawn. ${ }^{147}$

The special legal and ethical consideration accorded artificial sustenance by legislatures, courts, and commentators is warranted by the selfevident reality that food and water are basic necessities and, as such, carry tremendous emotional significance. ${ }^{148}$ As a result, some commentators have suggested that providing artificial sustenance to those unable to care for themselves is of special syinbolic inmportance as opposed to other forms of treatment. ${ }^{149}$ Others insist that the essential life-sustaining quality of sustenance requires the provision of nutrition and liydration to all patients in all circumstances. ${ }^{150}$ However, an emerging majority of physicians, ethicists, and lawyers advocate that medical mterventions supplying artificial sustenance should be treated no differently than other medical procedures. ${ }^{151}$

Medical enteral procedures are procedures in which nutritional formulas and water are introduced into the patient's stomach or intestine by ineans of a tube, such as a gastrostomy tube or nasogastric tube.

Parenteral nutritional procedures are procedures in which nutritional formulas and water are introduced into the patient's body by ineans other than the gastrointestinal tract. Such procedures include total parenteral nutritional support (TPN), in which a formula capable of inaintaining the patient for prolonged periods is infused into a vein-usually a large, central vein in the patient's chest-and intravenous procedures in which water and/or a formula supplying limited nutritional support is introduced into a peripheral vein.

HASTINGs' Guidelines, supra note 6, at 140-41; see also Dresser \& Boisaubin, Ethics, Law, and Nutritional Support, 145 ARCH. INTERNAL MED. 122, 122-23 (1985) (discussing the various medical procedures for providing nutrition to patients unable to eat naturally).

146. See infra notes $156-62$ for discussion of this judicial consensus.

147. Twenty-two states have exphicitly excluded artificial nutrition and hydration. National Legal Center Staff, supra note 50, at 357 n.216. See, e.g., FLA. STAT. ANN. § 765.03(3) (b) (West 1986) (specifically excluding the "provision of sustenance" from its defimition of "life-prolonging procedure" which a competent patient has the right to declime); Mo. ANN. ST.AT. \$ 459.010(3) (Vernon Supp. 1988) (specifically excluding "the performance of any procedure to provide nutrition or hydration" from its definition of life-prolonging procedures which a competent patient may direct to be withheld or withdrawn); see also, e.g., ARIZ. REV. STAT. ANN. \$36-3201(4) (1986); CoNN. GEN. STAT. § 19a-570(1) (Supp. 1987); IlL. ANN. STAT. ch. 1101/2, para. 702(2)(c) (Smith-Hurd Supp. 1987); TENN. CODE ANN. $§ 32-11-103(5)$ (Supp. 1987); WIS. STAT. ANN. $\$ 154.01(5)(b)$ (West Supp. 1987).

148. See Hastings' Guidelines, supra note 6, at 59; President's Comm'N, supra note 6, at 192 n.52; see also, e.g., Barber v. Superior Court, 147 Cal. App. 3d 1006, 1016, 195 Cal. Rptr. 484, 490 (1983); In re Conroy, 98 N.J. 321, 372, 486 A.2d 1209, 1236 (1986).

149. See, e.g., Callahan, On Feeding the Dying, 13 Hastings Center ReP., Oct. 1983, at 22; Derr, Nutrition and Hydratrion as Elective Therapy: Brophy and Jobes from an Ethical and Historical Perspective, 2 Issues L. \& MED. 25 (1986).

150. See, e.g., Derr, Why Food and Fluids Can Never Be Denied, 16 Hastings Center ReP., Feb. 1986, at 28, 30; Horan \& Grant, The Legal Aspects of Withdrawing Nourishment, 5 J. LEGAL MED. 595, 601 (1984); see also, Derr, supra note 149, at 38.

151. See, e.g., A.M.A. STATEMENT, supra note 42, at 12-13 (equating "artificially or 
The Conroy decision is particularly significant in this respect because it held that the benefits and burdens of artificial nutrition and hydration should be evaluated in the same inanner as other forms of lifesustaining treatment. ${ }^{152}$ This issue was not exphicitly addressed im any reported case before the Severns decision in 1980.153 For example, removal of the nasogastric feeding tube and antibiotic administration were not specifically addressed in Quinlan. ${ }^{154}$ The Court authorized removal of the respirator only, ${ }^{155}$ and did not consider the legitimacy of any decision to forego artificial nutrition and hydration. In subsequent

technologically supplied respiration, nutrition or hydration" with other forms of life-sustaining medical treatment for purposes of defining the right of the patient to forego those medical therapies); HASTINGS' GuIDELINES, supra note 6, at 61 ("all medical techniques for supplying nutrition and hydration that involve bodily invasion should be a matter of choice by the patient or surrogate"); President's CoMm'N, supra note 6, at 2-3 (life-sustaining treatment, which a patient has a voluntary choice to forego, imcludes "special feeding procedures"); Cassell, Life as a Work of Art, 14 HASTings Center ReP., Oct. 1984, at 35 ("there is no theoretical difference between the refusal to eat and the refusal of any other [medical] treatment") (emphasis omitted); Dresser \& Boisaubin, supra note 145, at 122 ("[W]e view nutrition as a medical intervention guided by considerations similar to those governing other treatment methods."); Lynn \& Childress, Must Patients Always be Given Food and Water?, 13 HAstings CeNTER ReP., Oct. 1983, at 17, 17-18; Meyers, Legal Aspects of Withdrawing Nourishment from an Incurably Ill Patient, 145 ARCH. INTERNAL MED. 125, 125 (1985) ("It seems no argument used to justify contimuing nourishment to a patient is absolute, from a moral, medical, or legal viewpoint."). But see, eg., Derr, Why Food and Fluids Can Never Be Denied, supra note 150, at 28-30 (identifying "[s]ix mutually remforcing biological, social, historical, and ethical consideratious [that] combine to provide a clear and plausible distmction between the withholding or withdrawal of food and fluids and the withholding or withdrawal of medical or surgical therapy." Id. at 28); Meilaender, On Removing Food and Water: Against the Stream, 14 HASTINGS CENTER REP., Dec. 1984, at 11 (maintaining that when society ceases to nourish, it aims to kill); Siegler \& Weisbard, Against the Emerging Stream: Should Fluids and Nutritional Support Be Discontinued?, 145 ARCH. INTERNAL MED. 129, 131 (1985) (recommending a "slow and conservative approach" to the issue).

152. In re Conroy, 98 N.J. 321, 374, 486 A.2d 1209, 1236-37 (1985).

153. In re Severns, 425 A.2d 156 (Del. Ch. 1980). In Severns, the Delaware Court of Chancery granted the prospective guardian's request "to discontimue all medical supportive measures desigued to kecp Mrs. Severns alive in a comatose state." 425 A.2d at 160 . Although the court's order instructed that "a feeding tube is not to be imserted in her trachea," 425 A.2d at 160, significantly, it did not direct the removal of the nasogastric tube which was then providing her with a life-sustaining formula. 425 A.2d at 157. See Horan \& Grant, supra note 150, at $616 \mathrm{n} .128$ (distinguishing between the passive means of supplying food througl a nasogastric tube and the aggressive means of performing surgery to insert a tube). It was not until 1983, in Barber v. Superior Court, $147 \mathrm{Cal}$. App. 3d 1006, 1016-17, $195 \mathrm{Cal}$. Rptr. 484, 489-91 (1983), that an appellate court explicitly considered this issue. More significantly, no state supreme court considered the particular relevance of nutrition and kydration until Conroy. See generally sources cited infra note 151.

154. In re Quinlan, 70 N.J. 10, 355 A.2d 347, cert. denied, 429 U.S. 922 (1976).

155. She is nourished by feeding by way of a nasal-gastro tube and is routinely examined for infection, which under these circumstances is a serious life threat . . . Her life accordingly is sustained by the respirator and tubal feeding, and removal from the respirator would cause her death soon, although the time cannot be stated with more precision.

Id. at 25-26, 355 A.2d at $655-56$ (emphasis added); see N. CANTOR, supra note 20, at 60 . Ms. Quinlan survived the removal of the respirator for over nine years. 
judicial analyses, the decision to forego artificial feeding has been, and continues to be, accorded special attention by the courts.

Nonetheless, since 1985, the supreme courts of New Jersey, ${ }^{156}$ Massachusetts, ${ }^{157}$ Arizona, ${ }^{158}$ Maine, ${ }^{159}$ and Washington ${ }^{160}$ have recogmized that the right to refuse life-saving medical treatment encompasses the right to refuse artificial nutrition and hydration. Appellate courts in three other states ${ }^{161}$ have also extended this right to include the right to refuse artificial sustenance and no higher court has reversed these decisions. Only several isolated trial court decisions have denied judicial permission to forego nutrition and hydration. ${ }^{162}$

156. See In re Conroy, 98 N.J. 321, 372-74, 486 A.2d 1209, 1235-37 (1985); see also In re Peter, 108 N.J. 365, 380-82, 529 A.2d 419, 427-28 (1987) (authorizing the removal of life-sustaining nasogastric tube from an incompetent 65 -year-old nursing home patient in a persistent vegetative state); In re Jobes, 108 N.J. 394, 529 A.2d 434 (1987) (permitting the removal of a life-sustaining food nutrition system from a 31-year-old woman).

157. Brophy v. New England Sinai Hosp., 398 Mass. 417, 497 N.E.2d 626 (1986) (honoring the substituted judgment of patient in persistent vegetative state that artifieial maintenanee of his nutrition and hydration be discontinued).

158. Rasmussen v. Fleming, 154 Ariz. 207, 741 P.2d 674 (1987) (en banc) (authorizing guardian of patient in chronic vegetative state to consent to removal of nasogastric tube under "best interests" standard governing surrogate decisionmaking).

159. In re Gardner, 534 A.2d 947, 954-55 (Me. 1987) (respecting a pre-accident decision not to be kept alive artificially in a persistent vegetative state under the theory of "substituted judgment" for a 25-year-old patient).

160. In re Grant, 109 Wash. 2d 545, 561-65, 747 P.2d 445, 452-55 (1987) (en banc) (permitting a 22-year-old in the terminal stages of a neurological disease and "in an almost vegetative state with little if any response to human contact" to forego artificial sustenance after her mother made a goodfaith determination that her daughter's best interests were served only by withholding life-sustaining treatruent).

161. Bouvia v. Superior Court, 179 Cal. App. 3d 1127, 225 Cal. Rptr. 297 (1986) (permitting a 28-year-old conpetent quadriplegic woman, afficted with cerebral palsy since birth, who was confined to a bed in a public hospital in total helplessness and receiving periodic morphine injections for chronic, severe arthritic pain, to compel hospital officials to remove a nasogastric tube despite her previously expressed intention to starve herself in order to end a painful life that sle considered to be futile and meaningless); Barber v. Superior Court, 147 Cal. App. 3d 1006, 195 Cal. Rptr. 484 (1983); Corbett v. D'Alessandro, 487 So. 2d 368, 371-72 (Fla. App. 1986) (permitting removal of nasogastric tube from an incompetent patient in persistent vegetative state); Delio v. Westchester County Medical Center, 129 A.D.2d 1, 16-19, 516 N.Y.S.2d 677, 687-89 (App. Div. 1987) (allowing wife of 33-year-old patient in cliromic vegetative state with no hope of recovery to act in aecordance with prior clearly expressed wishes of patient to have feeding and hydration tubes discontinued); see also In re Hier, 18 Mass. App. Ct. 200, 207-08, 464 N.E.2d 959, 964 (1984) (determining that 92 year-old incompetent patient could forego the surgical procedures necessary to provide her with adequate nutrition).

162. In re Visbeck, 210 N.J. Super. 527, 510 A.2d 125 (1986) (appointing a guardian for an incompetent 90 -year-old patient in order to obtain consent to surgical implantation of a feeding tube); In re Clark, 210 N.J. Super. 548, 510 A.2d 136 (1986), aff'd, 216 N.J. Super. 497, 524 A.2d 448 (1988) (appointing a guardian for a partially paralyzed 45-year-old patient with organic brain damage to consent to an enterostomy needed to prevent death by starvation and dehydration); In re Vogel, 134 Misc. 2d 395, 512 N.Y.S.2d 622 (N.Y. Sup. Ct. 1986) (denying authorization to remove nasogastric tube from a patient in a chronic vegetative state with no hope of any improvement); In re Kerr, 135 Misc. 2d 1076, 517 N.Y.S.2d 346 (N.Y. Sup. Ct. 1986) (refusing to order discontinuance of life-sustaining abdominal feeding tube from 83-year-old patient disabled by stroke because there 


\section{Inadequacy of the Current Standard: The Reluctance of Courts to Make Ethical Choices}

The courts have thus far been reluctant to articulate an adequate legal standard to govern this area because of the legitimate discomfort generated by authorizing themselves, or any surrogate or health care professional, to make a "quality of life" judgment for an incompetent patient. $^{163}$ The courts have accepted as ethically sound the concept that a competent patient may decide to limit treatment based on of the anticipated quality of his or her own life. If, however, a surrogate makes sucli a "quality of life" decision for a patient, this judgment could be challenged as arbitrary and unjust. Judgments about the quality of life clearly reflect the values, preconceptions, and biases of the person making the judgment. Hence, it is feared that surrogates may project their own attitudes about "quality of life" onto the patient in the decisionmaking process. ${ }^{164}$

Consequently, courts have cautiously avoided adopting any standard for that withdrawal of life-sustaining medical treatment from incompetent patients that lacks some objective foundation. But a failure to permit surrogates any "quality of life" judgments "may condemn some patients to lives of indigmity, pain, or burden that no person with decisionmaking capacity would choose."165 Part III of this Comment offers an objective "quality of life" criterion, based on the patient's capac-

was not a clear and compelling indication from the patient that he wanted it discontinued); Workmen's Circle Home and Infirmary for the Aged v. Fink, 135 Mise. 2d 270, 514 N.Y.S.2d 893 (N.Y. Sup. Ct. 1987) (refusing to grant the daughters of a semicomatose 79-year-old patient suffering from inoperable tumor authority to remove or prevent intravenous feeding or antibiotic treatment of mother, even though they established that it was their mother's wish that her life not be extended artificially since the provision of nutrients and medication is a nonintrusive medical procedure, the discontinuance of which would artificially hasten the inother's death).

163. See, e.g., In re Gardner, 534 A.2d 947, 955 (Me. 1987) (concluding that "personal weiglling of values is the essence of self-determination. In ruling to respect the personal choice made by Gardner, therefore, we judges do not ourselves engage im an independent assessinent of the value of his life ... . We are only recognizing and effectuating his right of self determination." (citation omitted)); Brophy v. New England Sinai Hosp., 398 Mass. 417, 434, 497 N.E.2d 626, 635 (1986) ("[W] make no judgment based on our own view of the value of Brophy's life since we do not approve of an analysis of state interests which focuses on Brophy's quality of life."); In re Conroy, 98 N.J. 321, 367, 486 A.2d 1209, 1232-33 (1985):

We expressly decline to authorize decision-making based on assessments of personal worth or social utility of another's life, or the value of that life to others. We do not believe that it would be appropriate for a court to designate a person with the authority to determine that someone else's life is not worth living simply because, to that person, that patient's quality of life or value to society seems negligible."

See also, eg., In re Beth Israel Medical Center, 136 Misc. 2d 931, 935, 519 N.Y.S.2d 511, 514 (Sup. Ct. 1987) ("It certainly would not be appropriate for a court to determine that someone's life is not worth living simply because in its subjective opinion the patient's quality of life or value to society is negligible.").

164. See Hastings' GUIDELINES, supra note 6, at 133-35.

165. Id. at 135 . 
ity for interpersonal relationships, as an analytic framework for addressing the difficult issue of determining the best interests of incompetent patients whose wishes cannot be known.

\section{III}

\section{In The Best Interests Of Incompetent Patients: A “QUALITY OF LifE" STANDARD}

Hundreds of "quahity of life" judgments daily confront medical personnel im dealing with incompetent patients. Whether to consider the "quality of hife" of a given patient when deciding to withhold life-sustaining treatment is one of the major moral dileinmas of modern medicine. ${ }^{166}$ Proponents of the use of a "quality of life" standard argue that an evaluation of the kind of life possible to a patient with and without treatment is unavoidable. On the other hand, for those who frame the issue as a concern for the right to life and society's duty to protect that right, all "quality of life" judgments must be summarily rejected. ${ }^{167}$

Any "quahty of life" judgment imphes that death may be more desirable to a particular patient than the level of existence that patient can achieve. This life-repudiating judgment offends those who view life as the supreme good to be preserved at all cost. ${ }^{168}$ However, if one maintains that-because life is a supreme good-"quality of life" judgments should never be made for incompetent persons whose wishes cannot be known, is not that person condemning certain individuals to a burdensome existence that most competent patients would not choose? Indeed, the religious and philosophical roots of the "sanctity of life" concept ${ }^{169}$

166. See id. at 133.

167. See, e.g., Connery, The Ethical Standards for Withholding/Withdrawing Nutrition and Hydration, 2 IssUES L. \& MED. 87, 93-94 (1986); Derr, supra note 149, at 38 ("[T] he judgement that such feeding is burdensome is self-deception at best, and exterminative deception at worst. Such a judgement is always a euphemism for the very different judgement that a patient's life is not worth living-that life per se is a burden, lebens unwertenlebens."); Ramsey, 'Euthanasia' and Dying Well Enough, 44 LINACRE Q. 43 (1977); Ramsey, Prolonging Dying: Not Medically Indicated, 6 HASTINGS CENTER REP., Feb. 1976, at 16 ("medically indicated/not medically indicated" suggested as a substitute for "ordinary/extraordmary" to underline the objective conditions and circumstances of the patient).

168. This particular version of the "sanctity of life" argument is commonly called vitalism.

169. See E. KEYSERIINGK, SANCTITY OF LIFE OR QUALITY OF LIFE 30-46 (1979). Keyserlingk believes that "any identification of vitalism witl the sanctity of life concept is erroneous and unsupported by a careful reading of both the religious and experiential/philosophical roots of the concept." Id. at 31. In arguing for the possibility of another, non-vitalistic, imterpretation of the "sanctity of life" principle, the author insists that "[ $t]$ he 'vitalistic' interpretations of sanctity of hife, to the extent that they reject human control over luman biological processes and matters of life and death, are denying to a greater or lesser degree man's shared dominion over crcation." Id. at 32; see also McCormick, supra note 142 at 34 ("We do not, in Christian perspectives, preserve [vital and metabolic processes with no human functioning or capacity] for their own sake; we are not vitalists.") (emphasis in original). 
and medical piety ${ }^{170}$ support the idea that biological life is not always a supreme good, and that "quality of life" concerns can express and protect a commitment to sanctity of life.

Due regard for the sanctity of life, however, prevents unsavory utilitarian factors from entering into the calculus of when to withhold lifesustaining treatment. ${ }^{171}$ As Richard McCormick has argued:

Every person is of "equal value." But not every life . . . is of equal value if we are careful to unpack the terms "life," "equal," and "value." If "life" means the continuation of vital processes but in a persistent vegetative state; if "value" means "a good to the individual concerned"; if "equal" means "identical" or the "same," especially of treatment, then I believe it is simply false to say that "every life is of equal value."172

Excluding utilitarian concerns such as social worth or status, a quality of life standard does not involve a coinparison of the hives of different people as the basis for treatinent decisions. More correctly, the only comparison is between the quality of life a particular patient presently enjoys and the quality that this patient would presumably deem acceptable. By neither drawing relative comparisons among the intrinsic worth of every person nor simultaneously insisting that every life is equally valuable to a particular patient, ${ }^{173}$ the quality of life standard proposed by this Comment attempts to reconcile the essential, but conflicting, values of patient autonomy and the sanctity of life.

\section{A. The Basic Concept: Personhood}

This Comment proposes a normative definition of "person" as a defensible way of incorporating quality of life considerations into the context of life-and-death decisionmaking. "Person" describes the individual who possesses the minimal features for a quality of life that should

170. See, e.g., Lo \& Jonsen, Clinical Decisions to Limit Treatment, 93 ANNALs INTERNAL MED. 764, 764 (1980) ("The physician has no moral or legal obligation to provide therapy that will not cure the disease or relieve symptoms."); HASTINGS' GuIDELINES, supra note 6, at 19 ("If a treatment is clearly futile in the sense that it will not achieve its physiological objective and so offers no physiological benefit to the patient, there is no obligation to provide the treatment.").

171. See, e.g., Hastings' Guidelines, supra note 6, at 9:

Due regard for the sanctity of life can guard against the erosion of respect for life in our society. By creating a presumption in favor of continued treatment, the sanctity of life can also help to protect gravely ill patients who are vulnerable. This presumption can reassure society that the termination of treatinent decisions are being made by individuals, institutions, or by society only after careful scrutiny and justification, and not out of ethically illicit motives. Sanctity of life, however, is a presumption; it does not by itself determine whether a particular treatment is appropriate for a patient.

172. McCormick, supra note 142, at 35 (emphasis in original).

173. Mischaracterization of a quality of life standard is clearly apparent in several court decisions. See generally Note, Natural Death: An Alternative in New Jersey, 73 GEO. L.J. 1331, 133639 (1985) (arguing that confusion over the Conroy court's rejection of quality of life as a factor in the decisionmaking process "stems from the Conroy court's incorrect equation of the term "quality of life' with the term 'value of life." "Id. at 1337). 
be preserved. From among the many possibilities that could be considered the essential characteristics of personhood, this Comment identifies humamity's social nature and an individual's minimum capacity for interpersonal relationships as what defines a "person."

\section{The Normative Concept of Person}

In deciding between life and death, a normative ${ }^{174}$ concept of "person" provides both an essential starting point in identifymg a carefully circumscribed "quality of life" standard and protection against bare utilitarian considerations.

What is the normatively human? The total human person constitutes more than simply physical existence. ${ }^{175}$ Since human life is rooted in experience and intuition, cven an atheist or agnostic might agree that life has a spiritual dimension which transcends the body. ${ }^{176}$ Even if one beheves that the spirit dies with the body, spirituality may be the key to one's concept of huinan dignity. Philosophical and ethical literature,

174. Normative is utilized in this Comment as a philosophical "term of art." Any concept asserted to be "normative" simply purports not to violate the philosophical principles of consistency and universalization. See W. FranKeNA, Ethics 12-94 (2d ed. 1973) (discussing various theories of normative ethics).

175. Kantian deontological ethics emphasizes the quality of hunan life. In Kant's view, only rational, self-aware, free huntan beings are "persons." Based largely on Kant's deontological ethics from Foundations of the Metaphysics of Morals and his inetaphysics from Critique of Pure Reason, one cominentator has asserted:

What is important about us as hunans is not our membership in the species Homo sapiens as such, but the fact that we are persons. This distinction between persons and humans will have important consequences for the ways in which one treats human personal life versus merely human biological hife.

H. T. ENGelhardT, JR., supra note 133, at 108; see also H. T. ENGelHARDT, JR., Mind-BodY: A CATEgorical Relation (1973) (a Kantian categorical account of "subject" which explores the differences between mental life and mere biological processes). A seeond Kantian scholar produces a similar analysis:

[A] person is not identical with merely the qualities inhering in a particular mind-body having certain spatiotemporal boundaries. Because we identify specific persons by pointing to their bodies or by referring to their performances, the logic of personal identity requires such boundaries; but this does not entail that the nature of personhood be similarly restricted. Personhood inheres in a complex network of relationships ....

Hoffman, Death and Dignity, in BeNEFiCENT EuthaNASIA 75 (M. Koh1 ed. 1975) (footnotes omitted); see also Tooley, Decisions to Terminate Life and the Concept of Person, in ETHiCal Issues RELATING To Life AND DEATH 91 (J. Ladd ed. 1979) ("Something is a person if and only if it is a continuing subject of experiences and other mental states that can envisage a future for itself and that can have desires about its own future states.").

In Cathohic natural law moral theology, the integrity of personhood-also called the "principal of totality"-subordinates the "physical aspect of man to the whole 'person' which also includes his spiritual aspect." Cahill, A 'Natural Law' Reconsideration of Euthanasia, 44 LINACRE Q. 47, 48-49 (1977).

176. Cf. Gustafson, The Contributions of Theology to Medical Ethics, 19 PersP. Biolocy \& MED. 247, 270 (Winter 1976) ("Functional equivalents of theology are present in the patterns of actions and the ethical thought of persons [involved in medical care and practice] who find theology to be a mcaningless intellectual enterprise."). 
therefore, often distinguishes between human biological life and human personal life. ${ }^{177}$ Medical literature, likewise, must address this issue when physicians attempt to define "death."178 These two reciprocally mfluential dimensions of life mutually define the concept of normative personhood. ${ }^{179}$

177. See generally sources cited supra note 175; B. HARING, MEdical ETHICs 142 (1973); E. KeyserlingK, supra note 169, at 49-105; E. KLUGE, The Ethics of Deliberate Death 81-93 (1981); Fletcher, Ethics and Euthanasia, in To LIVE AND To DIE 113-22 (R. Williams ed. 1973) ("It is personal function that counts, not biological function. Humanness is understood as primarily rational, not physiological. This 'doctrine of man' puts the homo and ratio before the vita. It holds that being human is more 'valuable' than being alive." Id. at 115); Fletcher, The 'Right' to Live and the 'Right' to Die, 34 HUMANIST, July-Aug. 1974, at 123 (arguing that 'in the balance of biological life and human life, being a man or a person is of more value than simply being alive.") McCormick, supra note 142, at 34-36. But see Meilaender, The Confused, the Voiceless, the Perverse: Shall We Give Them Food and Drink?, 2 Issues L. \& MED. 133 (1986) (the finite body is the locus of the selftranscendent person and that counection should not be severed).

178. Patients with irreversible cessation of all functions of the entire brain (including the brain stem), determined in accordance with accepted inedical standards, are considered medically and legally dead. See D. Meyers, Medico-Legal IMPLICATIONS OF DeATH AND DYING, 23-58 (1981 \& Supp. 1985); Ad Hoc Committee of the Harvard Medical School to Examine the Definition of Brain Death, A Definition of Irreversible Coma, J. A.M.A., Aug. 5, 1968, at 337.

The President's Commission, supra note 6, recommended the adoption of the Uniform Determination of Death Act (UDDA, Feb 1981), proposed by the American Medical Association, the American Bar Association, and the National Conference of Commissioners on Uniform State Laws. The Act reads: "An individual who has sustained either (1) irreversible cessation of circulatory and respiratory functions, (2) irreversible cessation of all functions of the entire brain, including the brain stem, is dead. A determination of death inust be made in aecordance with accepted medical standards." Solnick, Withdrawal and Withholding of Life-Support in Terminally Ill Patients, 3 MED. LAw 309, 312 (1984). By 1983, 29 states had adopted a statutory definition of brain death, in one of three variant forms. Meyers, supra, at 17 (Supp. 1985); see, e.g., CAL. Health \& SAFety CODE $\S 7180$ (West Supp. 1988).

179. One of the leading exponents of a distinction between human biological hfe and human personal life is Karl Rahner, the recently deceased German philosopher and theologian. Rahner accepted Kant's "turn to the subject" as well as modern philosophy's focus on "subjectivity." By using the Marechalian version of Kant's transcendental method, Rahner spent his philosophical career highlighting the distinctively personal characteristics of human nature. The normatively human for Rahner is the self-conscious "spirit in the world," or alternatively, the self-disposing "person in the world."

Rahner's ontology attempts to understand human nature as including two reciprocally influential dimensions: human nature and person/subject. The "person/subject" category appears as the constant correlative of nature wherever the latter has normative impact. "Nature" desiguates what is essential in a human being, the permanent limits of human existence that are common to all men and women, while "person/subject" specifies what is unique and inimitable at the core of human freedom and creativity. Human nature consists of nothing more nor less than the conditions of possibility of conscious freedom by which the "spirit/person in the world" shapes hiun or herself in time and history. Nature is "essence" considered precisely in relation to this uniquely characteristic activity of the human being-conscious self-possession (knowing) and self-disposal (freedom) of the human being as subject. See K. RAFNER, Foundations of Christian FaITH: AN INTROduction to THE IdEA OF ChristianITY 24-43 (Dych trans. 1982); Rahner, The Experiment with Man, in TheologiCal INVESTIGATIONS IX: WRITINGS OF 1965-67 1212 (Harrison trans. 1972); Rahner, On the Question of a Formal Existential Ethics, in THEOLOGICAL INVEstigations II: MAN IN THE CHURCH 217 (H. Kruger trans. 1963); Bresnalian, Rahner's Ethics: Critical Natural Law in Relation to Contemporary Ethical Methodology, 56 J. RELIGION 36 (1976). 
Human biological life is the condition for the possibility of human personal life. Alternatively, biological existence is not simply a value in itself, but a value as the basis of human existence. Therefore, biological hife should be prolonged with all appropriate and reasonable means only insofar as prolongation supports human personal life. For this reason alone, when continued life cannot offer the necessary conditions of ineaningful personal existence, it no longer constitutes a good for that mdividual. ${ }^{180}$

\section{The Essential Characteristic of Personhood: The Capacity for Interpersonal Relationships}

The essential characteristic of personhood is neither self-evident nor directly determinable froin empirical evidence alone. Identification of this essential characteristic is a philosophical enterprise involving prejudgments and presumptive ethical commitments. Reflecting on the problem of personhood, philosophers have generally devised lists of necessary, and possibly sufficient, conditions for being a person. ${ }^{181}$ Two properties-self-consciousness and rationahty - have figured most prominently in these notions of personhood. ${ }^{182}$ Other authors, however, have identified a third characteristic, the capacity for interpersonal and social relationships, as the defining characteristic of personhood. ${ }^{183}$

180. Several authors assert that continued biological life constitutes a good for a person only if it can offer the conditions for meaningful personal existence. See E. KEYSERLINGK, supra note 169, at 60-70; Cahill, supra note 175, at 47-52; Fletcher, The 'Right' to Live and the 'Right' to Die, supra note 177, at 123; McCormick, supra note 142, at 32-33. But see R. SHERLock, Preserving LiFE: Public Policy and tHe Life Not Worth Living 142 (1986) (distinction between "human being" and "person" is evasive and expresses unacceptable belief that the human being qua biological entity is not valuable enough to merit normal rights and protections); Meilaender, supra note 177 .

181. See, e.g., Dennett, Conditions of Personhood in The Identities of Persons 175-96 (A. Rorty ed. 1976) (identifying six familiar themes as necessary conditions of personhood: (1) rationality; (2) intentionality; (3) stance; (4) reciprocity; (5) verbal coinmunication; and (6) selfconsciousness); Feinberg, The Problem of Personhood, in Contemporary Issues in Bioethics 108-16 (T. Beauchamp \& L. Walters 2d ed. 1982) (characterizing the following properties as sufficient conditions of personhood: (1) consciousness; (2) possession of a self-concept; (3) selfawareness; (4) the capacity to experience emotions; (5) the capacity to act on one's plans; and (6) the capacity to feel pleasure and pain.); Fletcher, Four Indicators of Humanhood - The Enquiry Matures, in ON Moral Medicine: Theological Perspectives in Medical Ethics 275-78 (S. Lammers \& A. Verhey eds. 1987) (identifying four possible essential traits of humanness-neocortical function, self-consciousness, relational ability, and happiness, but concluding that neocortical function is the "first-order requirement and the key to the definition of a human being." Id. at 276.).

182. See, e.g., Dennett, supra note 181 , at 177-78.

183. D. CRANE, The SANCTITY OF SOCIAL LIFE (1975) (concluding that many physicians place a higher value on social interaction than on bodily life and thus are more willing to let patients die for this "quality of life" reason); E. KEXSERLINGK, supra note 169, at 60, 70; R. MCCORMiCK, How BRAVE A NEw WORLD?: Dilemmas in BIOETHICS 339, 349 (1985); Veatch, Defining Death Anew: Technical and Ethical Problems, in CONTEMPORARY IsSUES IN BIOETHICS, supra note 181, at 278. 288; see also Jonsen \& Garland, Critical Issues in Newborn Intensive Care: A Conference Report and Policy Proposal, 55 Pediatrics 756, 760-61 (emphasis added): 
Philosophical presuppositions clearly distinguish self-consciousness and rationality from the capacity to relate. Self-consciousness and rationality portray a person as an individual standing out in bold rehef against the background of society. In contrast, the capacity to relate accentuates the social character of liuman life. Although modern philosophy has debunked inuch of the social and relational qualities once so central to the idea of person, ${ }^{184}$ this Comment maintains that personhood is naturally and essentially grounded in a social and moral commumity. Hence, any atteinpt to identify the essential characteristic of personhood inust consider the social dimension of human life.

Despite identifying social interaction as the essential characteristic of personhood, the property of consciousness remains important to this analysis. Consciousness is, without doubt, a necessary condition for the presence of personhood. Although the inedical consensus defines "brain death" as whole-brain death, ${ }^{185}$ some philosophers have argued otherwise. ${ }^{186}$ Philosophers presuine on metaphysical grounds that death may be characterized as loss of consciousness, rationality, or awareness. Some, including Robert Veatch, ${ }^{187}$ argue more precisely that death is the irreversible loss of the einbodied capacity for social interaction. If the experiential and social aspect of a luman being is central to personhood, and if the cerebral cortex controls experiential and social functioning, then the death of the person should be equated with the irreversible destruction of the cortex. It is illogical to equate personal deatl with the

The responsibility of the parents, the duty of the physician, and the interests of the State are conditioned by the medico-moral principle, "do no harm, without expecting compensating benefit for the patient." Life-preserving intervention should be understood as doing harm to an infant who cannot not survive infancy, or will live in intractable pain, or cannot participate even minimally in human experience. [By this condition the authors understand] some inherent capability to respond affectively and cognitively to human attention and to develop toward initiation of conmunication with others.

A related concern, freedoin, has been suggested by other authors. See, e.g., B. HARING, supra note 177 , at 142 (freedom can be defeated by a total lack of consciousness, the existence of grave defects, or suffering); Kautzky, Der Arzt, 15 ARzT und CHRIST 138 (1969) ("Since human life is the condition for the realization of human freedom, it should be prolonged with all appropriate and reasonable means insofar as prolongation according to a competent estinate can serve this goal.").

184. See A. MACINTYre, AFTer VIRTUE 32-36, 216-22 (1984).

185. For a discussion of the medical defimition of death, see supra note 178 and accompanying text.

186. See, eg., H. T. ENGELHARDT, THE Foundations of BIoETHics, supra note 175, at 21011 (arguing toward a higher-brain-centers defimition of death); Smith, Legal Recognition of NeoCortical Death, 71 CoRNell L. Rev. 850, 861-62 (1986):

Giving legal recognition to neocortical death, however, could advance the analysis of the sensitive issue of forgoing or withdrawing nourishınent and artificial life-support systems in cases involving incompetent terminally ill patients (infants and adults) who nevertheless retain cognitive functions by forcing physicians and families to focus on the distinction between patients who are conscious and alive, and patients who are irreversibly noncognitive and, therefore, dead.

See also Wanser \& Adelstein, supra note 6, at 958-59.

187. Veatch, supra note 183, at 281-283. 
irreversible destruction of all brain function since the cerebral cortex is the locus of higher awareness and the subcortical regions are just gateways for vegetative functions.

Having accepted the philosophers' viewpoint, the key issue becomes how much consciousness is required for personal life to exist. One may concede that the absence of all sentience and consciousness signals the death of a person, yet still maintain that the presence of minimal sentience and consciousness is imsufficient to establish personhood. ${ }^{188}$ Therefore, the capacity for social interaction hinges on the existence of consciousness: ${ }^{189}$ without a functioning cerebral cortex-the physiological locus of consciousness ${ }^{190}$ - a minimum capacity to relate would be impossible. The presence of some brain activity beyond vegetative functions, however, does not imply the presence of a person. This Cornment sets the threshold for personhood higher than minimal consciousness. Personhood requires the existence of a level of consciousness which can maintain a minimum capacity for interpersonal relationships.

When this capacity is totally and irreversibly absent, continuing physical life offers the mdividual no personal benefit. The obligation to prolong biological life is foremost only msofar as that individual's hife provides the opportumity to nurture relationships as life's central endeavor. ${ }^{191}$ To preserve life totally void of this relational capacity, some argne, is to violate our notions of the sanctity of life. ${ }^{192}$

Althougli most commentators and courts have correctly rejected the Conroy "pliysical pain test" as the sole criterion in determining a patient's best interests, ${ }^{193}$ the presence of severe and intractable pain or suffering may so overwlielm its subject as to preclude personal relationships. ${ }^{194}$ If health care providers can adequately assess the degree of pain experienced by an mcompetent patient, ${ }^{195}$ the continuing burden of such pain inay morally justify ceasing life-sustaining treatment. Again, the good of the whole human person is central, not simply the perpetuation of physical existence.

188. H. T. Engelhardt, JR., The PRinciples of Bioethics, supra note 175, at 212.

189. E. KEYSERLINGK, supra note 169 , at 99.

190. See Cranford, supra note 2, at 27.

191. Cf. Callahan, The Sanctity of Life, in UPDatiNg LIFE AND DeATH 181-250 (D. Cutler ed. 1969) (an atheist or agnostic humanist would agree that since life is the fundamental and irreplaceable condition of the experience of all human values, it is a basic, or the basic value and must not be destroyed without grave cause).

192. See, e.g., HASTINGS' GuIDELINES, supra note 6, at 9 ("Sanctity of life, however, is a presumption; it does not by itself determine whether a particular treatment is appropriate for a patient."); McCormick, supra note 142, at 35.

193. See supra notes 121-30 and aceompanying text.

194. See E. KeYSERLINGK, supra note 169 , at 104.

195. For discussion of the medical reality of pain and the possibility of an accurate assessment, see supra note 126. 
A fundamental condition of all other human values, biological life is usually considered essential and thus to be preserved insofar as it can ground these values. Morality (and potentially law as well) does not abandon the commitment to the sanctity of life by recognizing the validity of quality of life considerations. Although the evaluation of relational capacity ${ }^{196}$ or the intensity of pain from the patient's viewpoimt is not subject to absolute certainty, it fashions a quality of life standard with a morally attractive objective component, rather than relying on subjective considerations such as social utility or relative worth.

\section{A Focus on Personhood Rather Than Treatment}

As discussed above, ${ }^{197}$ most physicians, ethicists and jurists have moved away froin the traditional language of "ordinary/extraordimary" means, labeling this ethical distinction ambiguous, relative, or no longer useful. ${ }^{198}$ Instead, inany champion a "proportionate/disproportionate"

196. A quality of life standard focusing on the capacity for interpersonal relationships is far from precise. There are diagnostic and prognostic complexities in determining the presence or absence of a level of consciousness sufficient to maintain a minimum capacity for interpersonal relationships. For instance, the degree of medical certainty about a diagnosis of the persistent vegetative state-the line-drawing between consciousness and unconsciousness-is still a controversial issue. See Cranford, supra note 2, at 29. Line-drawing between levels of consciousness is even more problematic. As Robert Veatch opines, "Even the most narrow criterion of the electroencephalogram alone may still give false positive diagnoses of living for holders of the social interaction concept." Veatch, supra note 183, at 287 . Determining the physiological locus of social interaction empirically requires greater scientific study, but, theoretically, at least, the line-drawing necessary for this quality of hife standard is possible. Regardless, "even though a line is not drawn in nature, it inay well be needed in practice." Bok, Death and Dying: Euthanasia and Sustaining Life: Ethical Views, in 1 ENCYCLOPEDIA OF BIOETHics 268, 277 (W. Reich ed. 1978).

197. See supra notes $134-44$ and accompanying text.

198. See, e.g., HASTINGs' Guidelines, supra note 6, at 5:

People sometimes distinguish "ordinary" froin "extraordinary" treatment by appealing to the prevalence of a treatment or its level of technological complexity. This is misleading because it focuses attention on factors that are ethically irrelevant to the decision to forgo treatment. Certain procedures for providing artificial nutrition and hydration, for example, are technologically rather complex, while administering chemotherapy is not; but it clearly does not follow that the latter is ethicaily required because it is "ordinary" (teehnically simple) while the former is optional because it is "extraordinary" (technically coinplex).

We reject the distinction. No treatment is intrinsically "ordinary" or "extraordinary." All treatments that impose undue burdens on the patient without overriding benefits or that simply provide no benefits may justifiably be withheld or withdrawn. While traditional definitions of "extraordinary" hinged on this comparison of benefits and burdens, the term has become so confusing that it is no longer useful.

See also President's CoMM'N, supra note 6, at 82-89 ('Despite its long history of frequent use, the distinction between ordinary and extraordinary treatments has now become so confused that its continued use in the formulation of public policy is no longer desirable." Id. at 88); P. RAMSEY, Ethics at the Edges of Life 153 (1978); R. Veatch, DEATH, Dying, and the Biological REvolution 105-15 (1976); McCartney, The Development of the Doctrine of Ordinary and Extraordinary Means of Preserving Life in Catholic Moral Theology Before the Karen Quinlan Case, 47 LINACRE Q. 215 (Feb. 1980). But see Smith, Judeo-Christian Teaching on Euthanasia: Definitions, Distinctions and Decisions, 54 LINACRE Q. 27, 29 (1987) ("Solne have recently and mistakenly converted this ordinary/extraordinary distinction into a proportionate/disproportionate calculus."). 
treatment standard and argue that this distmction has moral significance. ${ }^{199}$ This standard msists that

the obligation to promote the patient's good involves identifying the benefits and burdens of the treatment from the patient's perspective. Then the question becomes: do the burdens of the treatment outweigh its benefits from the patient's perspective? If they do, it is ethically acceptable to withhold or withdraw the treatment. ${ }^{200}$

Any "quality of life" standard inherently requires a patient (or surrogate) to identify the benefits and burdens of a medical treatment. This ethical deliberation focuses not on the technology itself, but rather on whether the burdens of a particular treatment are worth enduring. For example, a proposed course of treatment could be extremely painful or mtrusive and still be proportionate treatment if the prognosis was for cure or for significant improveunent in the patient's condition. On the other hand, a treatment which produces ouly minor discounfort could still be considered disproportionate to the potential benefits if it would not significantly improve tlie patient's condition. ${ }^{201}$ In the case of surrogate decisionmaking for incompetent patients whose wishes cannot be known, some legitimately fear that this approacl can result in subjective discrimination agamst tlie mcompetent, violating their rights and undermining society's grasp on the sanctity of every life. ${ }^{202}$

It is possible to establish a necessary modicum of objectivity to allay these fears of subjective discrimination against certain incoinpetent patients by using, the "quahty of life" standard proposed in this Comment. Whetlier an incompetent patient should subinit to a particular treatment would depend on the reasonable person's objective valuation. The existence of a minimum capacity for interpersonal relationships would, as a thresliold matter, determine the presence or absence of human personal life. Given this Comment's analysis of normative concept of "person,"203 the reasonable person could then objectively evaluate tlie likehihood that the treatment would preserve or.inprove huinan

199. See, e.g., President's Comm'N, supra note 6, at 82-89; Kelly, The Duty of Using Artificial Means of Preserving Life, 11 Theological Srud. 203, 213-17 (1950) (although framed within the traditional ordinary/extraordinary distinction, Kelly emphasized not the technique itself, but its effect on the patient; that is, benefits versus burdens); Sacred Congregation for the Doctrine of the Faith, Declaration on Euthanasia (May 5, 1980), reprinted in PRESIDENT's COMM'N, supra note 6, at 306 (endorsing the use of proportionate/disproportionate means analysis which includes "taking into account the state of the sick person and his or her physical and moral resources").

200. HASTINGS' Guidelines, supra note 6 , at 19.

201. See Barber v. Superior Court, 147 Cal. App. 3d 1006, 1018-19, 195 Cal. Rptr. 484, 491 (1983) (cited with approval in In re Conroy, 98 N.J. 321, 370, 486 A.2d 1209, 1234-35).

202. See, e.g., supra note 171. For the religious and secular sources of the "sanctity of life" principle, see R. Gula, What ARe They Saying About Euthanasia? 26-31 (1986) and McCormick, Life and Its Preservation, reprinted in Notes ON MORAL ThEOLOGY 1981-1984, 31,37 (1984).

203. See supra notes $174-80$ and accompanying text. 
personal life. ${ }^{204}$ A particular incompetent patient, therefore, would benefit from the restoration, maintenance, or enliancement of personliood, and not qualities subjectively determined by a surrogate. By imputing to the incompetent patient whose wisles cannot be known the normative concept of "person," a surrogate decisionmaker can objectively deem certain life-sustaining medical treatments so burdensome to a particular patient as to be nonobligatory.

\section{B. Operational Guidelines}

No decision to withhold life-sustaining medical treatınent on the basis of a minimal capacity for interpersonal relationships sliould be made by a surrogate decisionmaker until the following suggested step-bystep procedure is coinpleted:

1) A competent authority must determine that the patient lacks decisionmaking capacity.

2) Healtlı care providers must determine witl reasonable certainty whether the incompetent patient lacks a minimum capacity for interpersonal relationships (i.e., the absence of sufficient consciousness for social interaction).

3) If this capacity is lacking, liealth care providers must provide a reasonable clinical prognosis as to whetler this particular patient will recover any capacity to relate.

4) If this capacity is judged to be irretrievably lost, a surrogate may legitimately decide to withhold life-sustaining treatment.

5) If this capacity is present, even minimally, or judged not irretrievably lost, the surrogate must evaluate the potential benefits and burdens of the life-sustaining treatment under consideration. A treatment is beneficial if it restores, maintains, or enhances human life.

6) If the projected burdens (for example, pain or intrusiveness) are disproportionate to the benefits received from the treatment, the surrogate may legitimately decide to withhold that particular life-sustaining medical treatment. If the capacity for interpersonal relationships is present, the burdens/benefits analysis must be applied to each medical treatment considered. ${ }^{205}$

204. See generally R. VEATCH, supra note 198, at 110-111 (noting that higher courts in several jurisdictions have apphed the reasonable person standard in informed consent cases).

205. It is quite possible that artificial nutrition and hydration, general nursing care, and efforts to make the patient coinfortable (including pain relief) can be judged beneficial to a particular patient, while einergency resuscitation, intensive care, advanced life support, and general medical care that includes antibiotics, drugs, surgery, and chemotherapy would be judged too burdensoine to that same patient. $C f$. Wanzer \& Adelstein, supra note 6, at 958 (drawing the distinction between intrusive inedical treatments and general medical care). 
These suggested operational guidelines allow a surrogate to determine the best interests of an incoinpetent patient whose wishes cannot be known without imposing his or her own values on the decisionmaking process. In sum, to allay the legitimate fears concerning subjective social worth evaluations, the best interests of an incompetent patient whose wishes cannot be known must be evaluated in terms of an objective standard. The "capacity for interpersonal relationships" is one such standard.

\section{Application of the Proposed Standard}

Consider the case of Mr. Q. ${ }^{206}$ Since Mr. Q has no one to speak for him, he is an incoinpetent patient whose wishes cannot be known. Any attempt to apply the "substituted judgment" standard would be an "exercise in fictional characterization."207 Therefore, this Coinment's proposed "quality of life" standard applies.

The hypothetical describes $\mathrm{Mr} . \mathrm{Q}$ as an imcompetent patient who is not in a persistent vegetative state and can interact with his environment in some limited ways. By definition, therefore, he possesses a certain, albeit minimal, level of consciousness. As outhined in the operational guidelines, a health care professional must evaluate $\mathrm{Mr}$. Q's consciousness to determine whether he retains the capacity for interpersonal relationships. Since the prognosis discounts any chance that his inental condition will improve, if medical personnel determine that $\mathrm{Mr}$. Q presently has an insufficient level of consciousness for imterpersonal relationships, a surrogate can opt to withhold the surgical procedures necessary to provide $\mathrm{Mr}$. $\mathrm{Q}$ with adequate nutritional support. One is ethically obhigated to maintain human biological life only as the condition for furthering human personal life. Since the possibility of personal life for Mr. $Q$ is irretrievably lost, the surrogate is not ethically obligated to maintain his biological life.

Consider a different scenario. Health care professionals determine that $\mathrm{Mr}$. $\mathrm{Q}$ does possess a level of consciousness sufficient to inaintain a minimum capacity for social interaction. Under the suggested operational guidelines, the surrogate must analyze the potential benefits and burdens to Mr. Q of additional surgery. The potential benefit of surgery is, of course, Mr. Q's contimued biological life which, in this scenario, also provides for the possibility of continued, albeit mimimal, personal life.

The burdens/benefits analysis, however, is inconclusive. It hinges on the perceived burden of stomach surgery to $\mathrm{Mr}$. $\mathrm{Q}$. If judged to be

206. See supra notes 1-5 and accompanying text.

207. Weber, supra note 84 , at 146; see supra notes $84-85$ and accompanying text (criticizing Saikewicz's application of "substituted judgment"). 
very intrusive or extremely painful, the burden of this particular surgery may be disproportionate to the potential benefit. In that case, the projected surgery would not be ethically mandated and could be withheld. On the other hand, if judged not intrusive or painful, the burden of surgery would be proportionate to the benefit of continued personal life and, therefore, obligatory. The surrogate should decide to withhold this particular hfe-sustaining surgery from Mr. $\mathrm{Q}$ in his best interests only if the medical personnel are certain that the surgery would be very intrusive or extremely painful.

\section{CONCLUSION}

" $[\mathrm{H}]$ ow we think, what we perceive, what we experience, and how we act are to a great extent shaped by our metaphors."208 The abiding metaplior for inedicime traditionally has been warfare: "the physician is the captain who leads the battle against disease, orders a battery of tests, develops a plan of attack, calls on the armainentarium of medicine, directs allied health personnel, treats aggressively, and expects compliance. Patients are expected to put up a good fight, not to give up."209 Biomedical progress is now forcing us to adapt traditional values in ways that might earher have seemed unimaginable and utterly unacceptable. Confronted with this dileinina, courts have been reluctant to adopt any standards for surrogate decisionmaking which embrace articulable values. Acceptimg the "quality of life" standard proposed above may signal the happy demise of metaphorical medical warfare and provide surrogate decisionmakers with a humane option-the latitude necessary to deterinine the true "best interests" of incompetent patients whose wishes cannot be known. Withholding treatment, henceforth, will no longer be seen as retreat; and death will no longer represent the ultimate defeat.

208. Childress, Refusal of Lifesaving Treatment by Adults, 23 J. FAM. L. 191, 196 (1984) (quoting G. LAKoff \& M. Johnson, Metaphors We Live By (1980)).

209. Id. 
